\title{
Secondary Metabolites from the Marine Sponges of the Genus Petrosia: A Literature Review of 43 Years of Research
}

\author{
Yeon-Ju Lee ${ }^{1,2, * \mathbb{D}}$, Yeonwoo Cho ${ }^{1,2}$ and Huynh Nguyen Khanh Tran ${ }^{1}$ \\ 1 Marine Natural Products Chemistry Laboratory, Korea Institute of Ocean Science and Technology, \\ 385 Haeyangro, Busan 49111, Korea; yeonwoo@kiost.ac.kr (Y.C.); hnktran@kiost.ac.kr (H.N.K.T.) \\ 2 Department of Applied Ocean Science, University of Science and Technology, Daejeon 34113, Korea \\ * Correspondence: yjlee@kiost.ac.kr; Tel.: +82-51-664-3350
}

check for updates

Citation: Lee, Y.-J.; Cho, Y.; Tran, H.N.K. Secondary Metabolites from the Marine Sponges of the Genus Petrosia: A Literature Review of 43 Years of Research. Mar. Drugs 2021, 19, 122. https://doi.org/10.3390/ md19030122

Academic Editor: Vida Šimat

Received: 2 February 2021

Accepted: 22 February 2021

Published: 25 February 2021

Publisher's Note: MDPI stays neutral with regard to jurisdictional claims in published maps and institutional affiliations.

Copyright: (c) 2021 by the authors. Licensee MDPI, Basel, Switzerland. This article is an open access article distributed under the terms and conditions of the Creative Commons Attribution (CC BY) license (https:/ / creativecommons.org/licenses/by/ $4.0 /)$.

\begin{abstract}
Sponges are prolific sources of various natural products that have provided the chemical scaffolds for new drugs. The sponges of the genus Petrosia inhabit various regions and contain a variety of biologically active natural products such as polyacetylenes, sterols, meroterpenoids, and alkaloids. This review aims to provide a comprehensive summary of the chemical structures and biological activities of Petrosia metabolites covering a period of more than four decades (between 1978 and 2020). It is also described in this review that the major groups of metabolites from members of the genus Petrosia differed with latitude. The polyacetylenes were identified to be the most predominant metabolites in Petrosia sponges in temperate regions, while tropical Petrosia species were sources of a greater variety of metabolites, such as meroterpenoids, sterols, polyacetylenes, and alkaloids.
\end{abstract}

Keywords: Petrosia; metabolite; geography; polyacetylene; sponge

\section{Introduction}

The oceans represent the largest habitat on earth and contain organisms with high biological and chemical diversity. The secondary metabolites of diverse marine organisms allowed these species to develop mechanisms that would enable them to survive in the ocean. Over 30,000 natural products have been isolated from marine organisms [1], and 1490 and 1554 new compounds were discovered recently as 2017 and 2018, respectively [2,3].

Marine invertebrates, such as sponges, cnidarians, bryozoans, echinoderms, and tunicates, exclusively inhabit aquatic environments [4]. They are either sessile or slow moving, have soft bodies, and lack morphological defense structures such as shells or thorns [5]. Therefore, it is not incidental that these organisms evolved chemical defense mechanisms against predation and overgrowth of fouling organisms [6,7]. The abundance and diversity of secondary metabolites synthesized for chemical defense provide an opportunity to examine the chemical entities with potential therapeutic applications.

Marine sponges (Porifera) have been the central focus of the research for the discovery of biologically-active secondary metabolites. As sponges are highly effective filter feeders, microorganisms in the surrounding water are actively swirled by the sponge-driven currents. While some of the microorganisms are immediately digested, others are retained within the sponge body. It was reported that associated microorganisms can account for up to $60 \%$ of the fresh weight of marine sponges, and are more diverse than can be estimated using current technology [8,9]. It is believed that these sponge-associated microorganisms such as bacteria, fungi, cyanobacteria, and unicellular algae may be involved in the biosynthesis of natural products that are isolated from the sponges, although the relationship between sponge and associated microorganisms are highly complex [10].

Several statistical studies on marine natural products have revealed that sponges are outstanding in number of isolated biologically-active compounds. Hu et al. have analyzed the temporal trend, chemical structure distribution, bioactivity groups, and species distribution of biologically-active compounds from marine organisms discovered 
during the 28 years from 1985 to 2012 [11]. In this study, the authors found out that approximately $75 \%$ of the compounds were isolated from marine invertebrates, and the highest proportion of bioactive compounds had been isolated from sponges. Another report, which covers 9812 marine natural products isolated from invertebrates discovered during 1990-2009, also showed that the highest proportion of metabolites could be traced to sponges $(48.8 \%)$ [12].

It is generally believed that there is a higher chance of discovering biologically-active sponge metabolites in habitats characterized by intense competition for survival due to their high biological diversity and density, such as coral reefs in tropical regions $[13,14]$. Following the principle that sponge chemical defense is mainly driven by predation pressure [15], it was hypothesized that chemical diversity is higher in the tropical region than the temperate region. This hypothesis is only partly supported, as it was reported that tropical and temperate benthic systems differ with regard to dominant consumption regimes. While fishes are dominant predators on reefs in tropical regions, temperate systems are characterized by mesopredators such as crustaceans, sea urchins, and gastropods [16,17].

Geographical location is clearly one of the most influential factors related to the variation in sponge metabolites; however, few studies have investigated the geographical variation in sponge metabolites in terms of yield or biological activity. The first study regarding this issue claimed the inverse relationship between latitude and toxicity in sponges [18]. The authors examined the toxicity of 78 sponge species collected in temperate (San Juan Island and Santa Catalina Island) and tropical regions (La Blanquilla reef and Zihuatanejo Bay) on fishes by measuring the time from exposure to death. They found that $9 \%$ of the sponge species in the regions of 48 degrees north were toxic and $75 \%$ of the sponges studied in the region of 19 degrees north were toxic. A study by Ruzicka et al. also demonstrated that sponge species on the temperate reefs in the South Atlantic Bight are a smaller chemical deterrent to fish predators than their counterparts at lower latitudes in the Florida Keys by measuring the palatability of sponge crude extracts quantitatively and comparing the results with those obtained by Pawlik et al. [14,19].

Results that are contradictory to those above have also been reported. A feeding assay with 17 pairwise comparisons conducted by Burns et al. showed no significant differences in deterrence between Red Sea and Caribbean sponges [20]. The field-based feeding experiments with diverse fish predators conducted by Becerro et al. showed similar results [21]. When 20 sponge species from tropical Guam and temperate Northeast Spanish coasts were compared, no significant difference was observed based on habitat. It is worthwhile to mention, however, that the percentage yield of crude organic extracts tends to be proportional to latitude, although the authors did not provide any comment on this. When a total of 20 sponge species in 10 species pairs were extracted, the tropical sponges were found to provide up to a 3.4 times higher yield than their temperate counterparts in nine pairs.

More recent studies focused on the intra-specific variability in secondary metabolites in terms of concentration. One such study examined Aplysina aerophoba, a common Mediterranean sponge known to contain large concentrations of brominated alkaloids [22]. When the concentrations of bromotyrosine alkaloids such as aerophobin-1, aerophobin-2, aplysinamisin-1, and isofistularin-3 were evaluated using HPLC according to the geographic location of its habitat, significant variation was observed at the largest (Canary Islands and Mediterranean, over $2500 \mathrm{~km}$ ) and the smallest (two sites less than $500 \mathrm{~m}$ apart) geographic scales. Another study evaluating the variability in metabolites of Stylissa massa came to a similar conclusion [23]. The concentrations of the bromopyrrole alkaloidse.g., hymenidine analogs, sceptrin, and oroidin-were measured using LC-MS analysis. Concentrations varied geographically across the Pacific basin, with American Samoa and Pohnpei exhibiting the greatest differences, and Guam and Saipan being the most similar to each other.

A very recent metabolomics study revealed the relationship between sponge metabolites and the geographic location. Total 139 specimens of Xestospongia spp. were collected 
in four locations-Martinique, Curacao, Taiwan, and Tanzania-and the extracts were analyzed by ${ }^{1} \mathrm{H}$ NMR and LC-MS, followed by statistical analysis (OPLS-DA); the collected samples were clearly grouped according to their location [24].

Experimental evidence supports this geographical trend of the sponge metabolites, although it is scattered throughout the literature. This review aims to compile this information and determine variations in metabolites according to geographical location using the genus Petrosia. Petrosia is one of the four genera (Acanthostrongylophora, Neopetrosia, Petrosia, Xestospongia) of the family Petrosiidae belonging to the order Haplosclerida, which is known as the most prolific source of secondary metabolites among sponges [12]. As of 2020, Petrosia genus includes 122 species belonging to two subgenera of Petrosia and Strongylophora, according to the Word Register of Marine Species (WoRMS). They are widely distributed throughout tropical and temperate waters, from intertidal zones to deep waters.

This review collects and compares information from peer-reviewed articles on secondary metabolites isolated from the sponges of the genus Petrosia. The articles were retrieved from the following databases: PubMed, Chemical Abstracts ${ }^{\circledR}$, ISI Web of Knowledge, Google Scholar. Based on the assumption that the latitude of sponge habitat plays an important role in the metabolite, the regions were divided into polar (above the Arctic Circle $\left(66.5^{\circ} \mathrm{N}\right)$ and below the Antarctic Circle $\left(66.5^{\circ} \mathrm{S}\right)$ ), temperate (between the Tropic of Cancer $\left(23.5^{\circ} \mathrm{N}\right)$ and the Arctic Circle and between the Tropic of Capricorn $\left(23.5^{\circ} \mathrm{S}\right)$ and the Antarctic Circle), and tropical area (between the Tropic of Cancer and the Tropic of Capricorn).

\section{Petrosia Metabolites}

\subsection{Polyacetylenes}

\subsubsection{Polyacetylenes Isolated from Temperate Petrosia Sponges}

Polyacetylenes are characteristic metabolites of Petrosia sponges inhabiting temperate regions above the Tropic of Cancer. Of the 38 publications regarding the secondary metabolites from temperate Petrosia sponges, 31 reported the isolation of polyacetylenes.

Mixtures of high-molecular weight polyacetylenes with 46-55 carbons were isolated from both the sponge P. ficiformis and its predator nudibranch Peltodoris atromaculata [25] in the Mediterranean Sea. These were the first reported polyacetylenes from Petrosia sponges, although some of the structural features of these-e.g., the aliphatic carbon chain length between the characteristic functional groups and stereochemistry-were not revealed. Five years later, the same research group isolated small amounts of two additional polyacetylenes, but their structural assignment remained incomplete [26]. Mixtures of five additional polyacetylenes up to 52 carbons long, isolated from P. ficiformis found in dark caves in the Mediterranean Sea, were also reported [27].

In 1989, polyacetylenes with two terminal 1-yn-3-ol-4-ene moieties and 46 total carbons isolated from Mediterranean P. ficiformis were completely identified and evaluated for their biological activity (Figure 1); the structures of petroformynes 1-4 (1-4) were elucidated, and it was shown that they inhibit sea urchin egg development and act as a potent toxin against Artemia salina [28]. The absolute stereochemistry of petroformynes was later elucidated by Mosher's method [29]. The minor analogs contained in the same species were added through further research [30-32]; petroformynes, isopetroformynes, and various oxidized or isomerized analogs (5-22) were reported. Most of these analogs exhibited lethality against brine shrimp. 


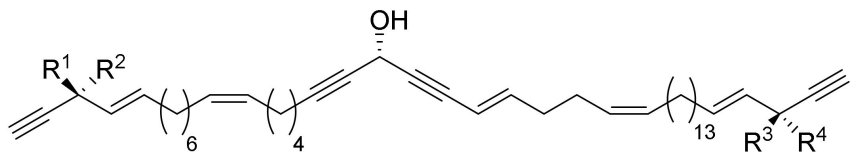

$1 \mathrm{R}^{1}=\mathrm{OH}, \mathrm{R}^{2}=\mathrm{H}, \mathrm{R}^{3}=\mathrm{OH}, \mathrm{R}^{4}=\mathrm{H}$; petroformyne 1

$5 R^{1}=R^{2}=O, R^{3}=R^{4}=0$; 3,44-dioxopetroformyne 1

$6 R^{1}=R^{2}=O, R^{3}=O H, R^{4}=H$; petroformyne 8

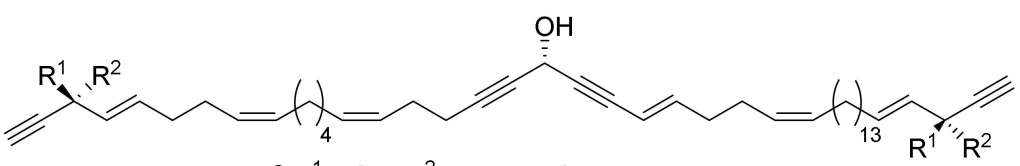<smiles>[R]C([R])(C#CC=CCCC=CC#C)C#CN(C)CC=CC(C)C=CC([R])([R])C#C</smiles>

$2 \mathrm{R}^{1}=\mathrm{OH} ; \mathrm{R}^{2}=\mathrm{H}$; petroformyne 2

$7 R^{1}=R^{2}=$ O; 3,44-dioxopetroformyne 2

$3 \mathrm{R}^{1}=\mathrm{OH}, \mathrm{R}^{2}=\mathrm{H}, \mathrm{R}^{3}=\mathrm{H}, \mathrm{R}^{4}=\mathrm{OH}, 4 E, 23 E$; petroformyne 3

$8 \mathrm{R}^{1}=\mathrm{OH}, \mathrm{R}^{2}=\mathrm{H}, \mathrm{R}^{3}=\mathrm{H}, \mathrm{R}^{4}=\mathrm{OH}, 4 E, 23 Z$; isopetroformyne 3

$9 \mathrm{R}^{1}=\mathrm{OH}, \mathrm{R}^{2}=\mathrm{H}, \mathrm{R}^{3}=\mathrm{H}, \mathrm{R}^{4}=\mathrm{OH}, 23 Z ; 4,5$-dihydroisopetroformyne 3

$10 \mathrm{R}^{1}=\mathrm{OH}, \mathrm{R}^{2}=\mathrm{H}, \mathrm{R}^{3}=\mathrm{R}^{4}=\mathrm{O}, 4 E, 23 Z ; 20$-oxoisopetroformyne 3

$11 \mathrm{R}^{1}=\mathrm{OH}, \mathrm{R}^{2}=\mathrm{H}, \mathrm{R}^{3}=\mathrm{R}^{4}=\mathrm{O}, 4 E$

$12 \mathrm{R}^{1}=\mathrm{R}^{2}=\mathrm{O}, \mathrm{R}^{3}=\mathrm{H}, \mathrm{R}^{4}=\mathrm{OH}, 4 E, 23 E$; petroformyne 6

$13 \mathrm{R}^{1}=\mathrm{R}^{2}=\mathrm{O}, \mathrm{R}^{3}=\mathrm{H}, \mathrm{R}^{4}=\mathrm{OH}, 4 E, 23 Z$; isopetroformyne 6

$14 \mathrm{R}^{1}=\mathrm{R}^{2}=\mathrm{O}, \mathrm{R}^{3}=\mathrm{H}, \mathrm{R}^{4}=\mathrm{OH}, 4 E ; 23,24$-dihydropetroformyne 6

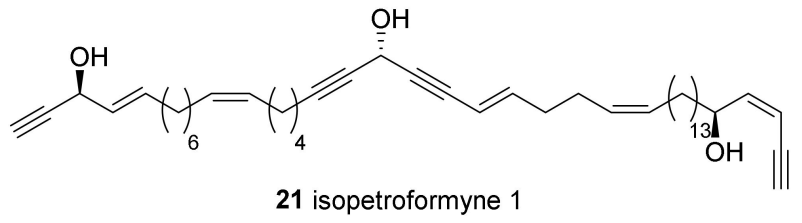<smiles>[R]C([R])(C#C/C=C\N(C)/C=C/C([R])([R])C#C)C#C/C=C/CC/C=C/C=C/C#C</smiles>

$4 \mathrm{R}^{1}=\mathrm{OH}, \mathrm{R}^{2}=\mathrm{H}, \mathrm{R}^{3}=\mathrm{H}, \mathrm{R}^{4}=\mathrm{OH}, 23 E$; petroformyne 4

$15 \mathrm{R}^{1}=\mathrm{OH}, \mathrm{R}^{2}=\mathrm{H}, \mathrm{R}^{3}=\mathrm{H}, \mathrm{R}^{4}=\mathrm{OH}, 23 \mathrm{Z}$; isopetroformyne 4 $16 \mathrm{R}^{1}=\mathrm{OH}, \mathrm{R}^{2}=\mathrm{H}, \mathrm{R}^{3}=\mathrm{H}, \mathrm{R}^{4}=\mathrm{OH} ; 23,24$-dihydropetroformyne 4 $17 \mathrm{R}^{1}=\mathrm{OH}, \mathrm{R}^{2}=\mathrm{H}, \mathrm{R}^{3}=\mathrm{R}^{4}=\mathrm{O}, 23 \mathrm{2} ;$ 20-oxoisopetroformyne 4 $18 \mathrm{R}^{1}=\mathrm{R}^{2}=\mathrm{O}, \mathrm{R}^{3}=\mathrm{H}, \mathrm{R}^{4}=\mathrm{OH}, 23 E$; petroformyne 7 $19 \mathrm{R}^{1}=\mathrm{R}^{2}=\mathrm{O}, \mathrm{R}^{3}=\mathrm{H}, \mathrm{R}^{4}=\mathrm{OH}, 23 \mathrm{Z}$; isopetroformyne 7 $20 \mathrm{R}^{1}=\mathrm{R}^{2}=\mathrm{O}, \mathrm{R}^{3}=\mathrm{H}, \mathrm{R}^{4}=\mathrm{OH} ;$ 23,24-dihydropetroformyne 7

21 isopetroformyne 1

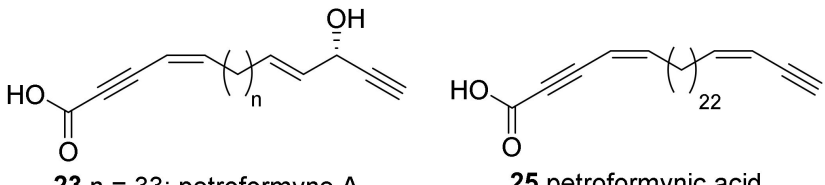<smiles>C#C[C@@H](O)/C=C/C(C)=C/CC/C=C/C#CC(O)C#CC/C=C/[C@@H](O)[C@H](O)/C=C/[C@@H](O)C#C</smiles>

$23 \mathrm{n}=33$; petroformyne A $24 n=35$; petroformyne $B$

25 petroformynic acid

22 petroformyne 5

Figure 1. Polyacetylenes isolated from Mediterranean Petrosia sponges.

Polyacetylene carboxylic acids-petroformynes A, B $(\mathbf{2 3}, \mathbf{2 4})$, and petroformynic acid (25)—were also reported [32]. Compounds 23 and 24 showed high lethality in brine shrimp assay. Compounds $\mathbf{2 3}$ and $\mathbf{2 4}$ showed high lethality in brine shrimp assay.

Isolation of polyacetylenes from Petrosia sp. inhabiting temperate regions of Japan was initiated from the discovery of the $\mathrm{C} 30$ polyacetylenes, petrosynol (26) and petrosynone (27) (Figure 2) [33,34]. In the case of petrosynol (26), the stereochemistry of hydroxymethine was revealed by measuring the Cotton effect of benzylated derivatives. This was the first report to completely elucidate the structure of polyacetylenes, including stereochemistry. Four more petrosynol derivatives (28-31) were reported by another research group [35]. These compounds inhibited the cell division of fertilized ascidian (Styela partita) eggs with $\mathrm{IC}_{50}$ values of $5.0-30.0 \mu \mathrm{g} / \mathrm{mL}$ and displayed toxicity in the brine shrimp lethality bioassay with $\mathrm{LC}_{50}$ values from $0.1-30.0 \mu \mathrm{g} / \mathrm{mL}$. Petroacetylene (32), a tetraketone derivative of 29 and 30, was also reported by a different research group [36]. 


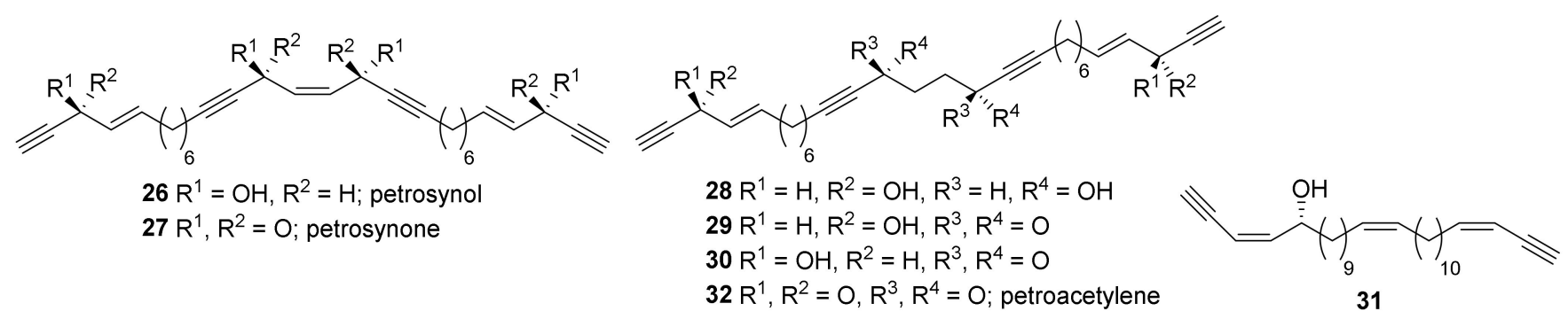

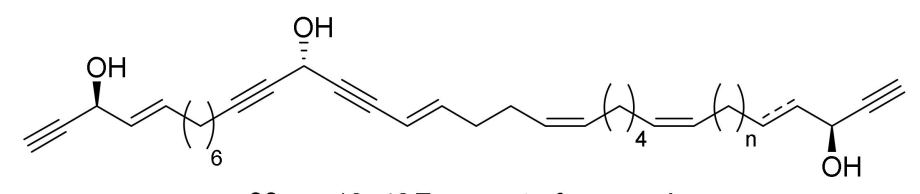

$33 n=13,42 E$, neopetroformyne $A$ $34 n=12,41 E$, neopetroformyne $B$ $35 n=13$, neopetroformyne $C$

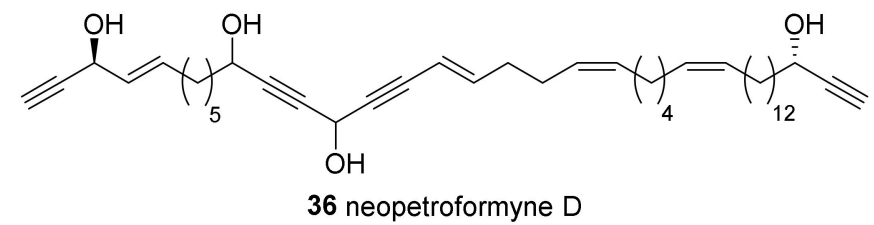

36 neopetroformyne D

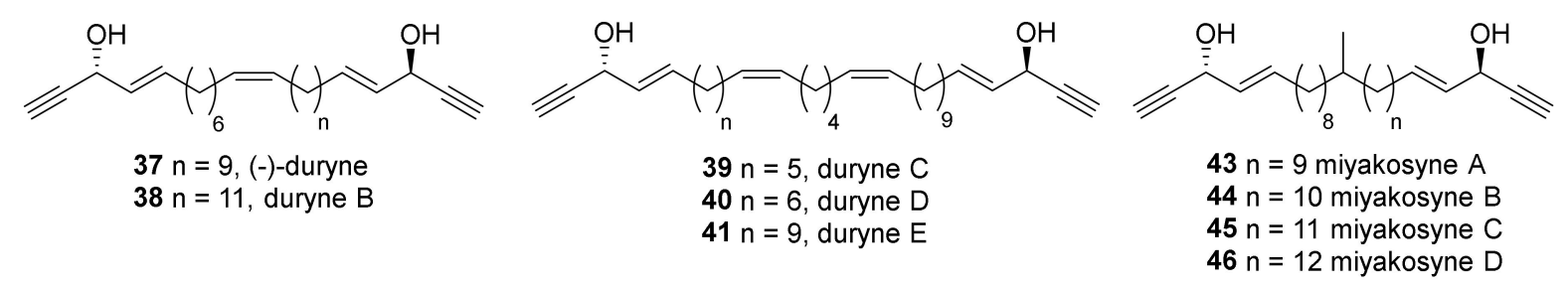<smiles>C#C/C=C\C(O)C(C)/C=C\C(C)=C/C=C/[C@H](O)C#C</smiles><smiles>C#C/C=C\[C@H](O)C(C)C(C)C(C)(C)C(C)/C=C/C(=O)C#C</smiles>
$48 \mathrm{~m}=11, \mathrm{n}=8$ miyakosyne $\mathrm{F}$

Figure 2. Polyacetylenic alcohols isolated from Japanese Petrosia sponges.

The petroformyne analogs were also isolated from a Japanese Petrosia sponge; petroformynes 1 and $4(\mathbf{1}, \mathbf{4})$ [37], in addition to the novel derivatives, neopetroformynes (33-36), were isolated [38]. The functional groups were identified based on NMR spectroscopy data including those from 2D NMR experiments such as COSY, HMBC, and TOCSY. The length of the alkyl chains was determined by analyzing FAB-MS/MS data and stereochemistry, except for that of neopetroformyne D (36), was revealed by the modified Mosher method. In this report, the authors suggested that neopetroformyne A (33) and petroformyne 1 (1) might share the same structures, as their NMR data were indistinguishable. The structure of 1, however, could not be reexamined by FAB-MS/MS due to a lack of remaining material. Neopetroformynes A-D (33-36) exhibited cytotoxicity against P388 murine leukemia cells with an $\mathrm{IC}_{50}$ values in ranging from 0.09 to $0.45 \mu \mathrm{g} / \mathrm{mL}$.

The related analogs, named durynes (37-42), were reported by the same research group [39]. Compound 37 ((-)-duryne) was found to be an enantiomer of (+)-duryne, which has previously been isolated from the marine sponge Cribrochalina dura collected off the shore of Staniel Cay $\left(24.2^{\circ} \mathrm{N}\right)$ in the Bahamas [40]. The taxonomy of Cribrochalina dura was later revised to be Petrosia, and the absolute configuration of each enantiomer was confirmed by the synthesis of both enantiomers [41].

Miyakosynes are also allyl propargyl alcohols or ketones like petroformyne derivatives, but they have a branched methyl group in the aliphatic chain in the middle. Six miyakosynes (A-F, 43-48) were isolated from the sponge Petrosia sp. collected at Miyako sea knoll in Japan [42]. The locations of methyl branches were determined by tandem FAB-MS/MS analysis, and the stereochemistry was assigned using the modified Mosher's method. Compounds $43-46$ and a mixture of 47 and 48 exhibited cytotoxicity against HeLa cells with $\mathrm{IC}_{50}$ values of $0.10,0.13,0.04,0.15$, and $0.30 \mu \mathrm{g} / \mathrm{mL}$. 
Petrosynes $(49,50)$ are polyacetylenic enol ethers isolated from a Petrosia sp. collected near Ishigaki Island (Figure 3) [43]. Followed by the deduction of the plane structure by spectroscopic analysis, all possible stereoisomers of $\mathbf{4 9}$ and $\mathbf{5 0}$ were synthesized enantioselectively, which showed both to consist of mixtures of $7 R$ and $7 S$ diastereomers.

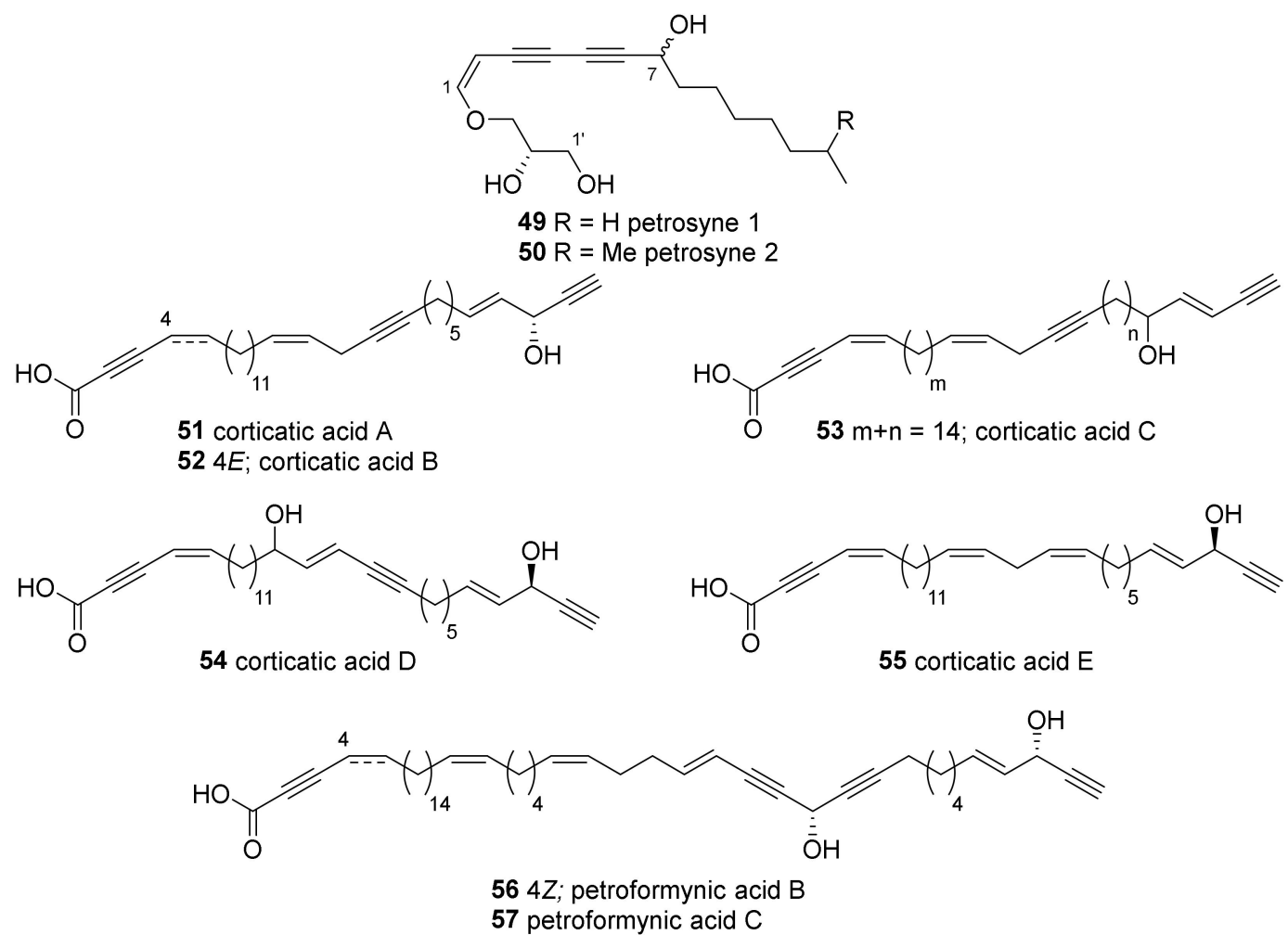

Figure 3. Polyacetylenic enol ether glyceride and carboxylate from Japanese P. sponges.

Polyacetylene carboxylic acids are another group of compounds isolated from Japanese Petrosia sponges. Five corticatic acids (51-55), which show antifungal activity against Mortierella ramanniana or Candida albicans, have been isolated from P. corticata $[44,45]$. Petroformynic acids $B$ and $C(56,57)$-analogous to petroformynes 4 and $3(4,3)$, respectivelywere isolated along with petroformynes 1 and $4(\mathbf{1}, 4)$ [37]. Compounds 56 and 57 inhibited the growth of P388 cells with an $\mathrm{IC}_{50}$ value of $0.4 \mu \mathrm{g} / \mathrm{mL}$.

Polyacetylenes isolated from Petrosia inhabiting Korean water are mostly petroformyne 1 (1) and petrosynol (26) analogs, which have at least one allyl propargyl alcohol at the terminus (Figure 4). Petrocortynes A-H (58-65) were isolated from the extract of Petrosia sp. collected along offshore from Keomun Island, South Sea of Korea [46,47]. The structures of these compounds were elucidated by extensive NMR experiments, including COSY, HETCOR, HMQC, HMBC, and TOCSY, and the stereochemistry was revealed by a modified Mosher's method. Petrocortyne C (60) possesses an unusual $\gamma$-pyrone ring, while the other analogs are linear $\mathrm{C} 46$ tetraacetylenes with a diacetylenic carbinol functionality in the middle. Petrocortynes A-C (58-60) showed significant brine-shrimp lethality and RNAcleaving activity and petrocortynes $\mathrm{D}-\mathrm{H}(\mathbf{6 1}-\mathbf{6 5})$ exhibited moderate to minimal cytotoxicity against a human leukemia cell line (K562) with $\mathrm{LC}_{50}$ values of 7.0-45.0 $\mu \mathrm{M}$. 
<smiles>[R]C([R])(C#C/C=C/C([R])([R])C#C)C#CC(C)/C=C\C=C/C=C/C=C/C#C</smiles>

$58 \mathrm{R}^{1}=\mathrm{H}, \mathrm{R}^{2}=\mathrm{OH}, \mathrm{R}^{3}=\mathrm{OH}, \mathrm{R}^{4}=\mathrm{H}, \mathrm{n}=14$; petrocortyne $\mathrm{A}$ $61 \mathrm{R}^{1}=\mathrm{OH}, \mathrm{R}^{2}=\mathrm{H}, \mathrm{R}^{3}=\mathrm{OH}, \mathrm{R}^{4}=\mathrm{H}, \mathrm{n}=14$; petrocortyne $\mathrm{D}$

$66 \mathrm{R}^{1}=\mathrm{OH}, \mathrm{R}^{2}=\mathrm{H}, \mathrm{R}^{3}=\mathrm{H}, \mathrm{R}^{4}=\mathrm{OH}, \mathrm{n}=14$

$67 \mathrm{R}^{1}=\mathrm{OH}, \mathrm{R}^{2}=\mathrm{H}, \mathrm{R}^{3}=\mathrm{H}, \mathrm{R}^{4}=\mathrm{OH}, \mathrm{n}=13$

$71 \mathrm{R}^{1}=\mathrm{OH}, \mathrm{R}^{2}=\mathrm{H}, \mathrm{R}^{3}=\mathrm{H}, \mathrm{R}^{4}=\mathrm{OH}, \mathrm{n}=15$

$72 \mathrm{R}^{1}=\mathrm{OH}, \mathrm{R}^{2}=\mathrm{H}, \mathrm{R}^{3}=\mathrm{H}, \mathrm{R}^{4}=\mathrm{OH}, \mathrm{n}=16$

$69 \mathrm{R}^{1}=\mathrm{H}, \mathrm{R}^{2}=\mathrm{OH}, \mathrm{R}^{3}=\mathrm{H}, \mathrm{R}^{4}=\mathrm{OH}, \mathrm{n}=14$; petrotetrayndiol $\mathrm{B}$

$83 \mathrm{R}^{1}=\mathrm{OH}, \mathrm{R}^{2}=\mathrm{H}, \mathrm{R}^{3}=\mathrm{R}^{4}=\mathrm{O}, \mathrm{n}=14$; petrotetraynol $\mathrm{A}$<smiles>[R]C([R])(C#CC(C)/C=C/C([R])([R])C#C)C#CC(C)C(O)/C=C/C(C)/C=C\C(C)/C=C\C#C</smiles>

$62 \mathrm{R}^{1}=\mathrm{H}, \mathrm{R}^{2}=\mathrm{OH}, \mathrm{R}^{3}=\mathrm{OH}, \mathrm{R}^{4}=\mathrm{H}$; petrocortyne $\mathrm{E}$ $74 \mathrm{R}^{1}=\mathrm{OH}, \mathrm{R}^{2}=\mathrm{H}, \mathrm{R}^{3}=\mathrm{OH}, \mathrm{R}^{4}=\mathrm{H}$

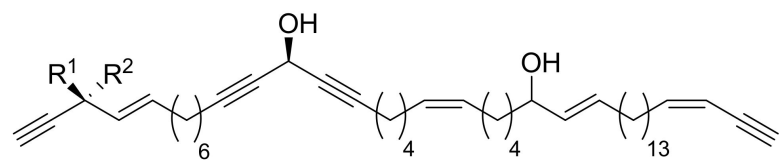

$64 \mathrm{R}^{1}=\mathrm{H}, \mathrm{R}^{2}=\mathrm{OH}$; petrocortyne $\mathrm{G}$

$76 \mathrm{R}^{1}=\mathrm{OH}, \mathrm{R}^{2}=\mathrm{H} ;(3 \mathrm{~S}, 14 \mathrm{R})$-petrocortyne $\mathrm{G}$<smiles>C#CC=CC=CC(C)=CC=CCCC=CC#CC(O)C#CC(C)C=CC(O)C#C</smiles>

68 14Z; petrotetrayndiol A

79 petrotetrayndiol $\mathrm{E}$<smiles>C#C/C=C\C(C)C(=O)N(C)C=CC(C)(C)C#CC(O)C#CC(C)C=CC(O)C#C</smiles><smiles>C#C/C=C\C=C/C=C/C=C/C(C)(O)C#CC(O)C#CC(C)/C=C/C(O)C#C</smiles>

81 petrotetrayntriol $A$<smiles>[R]C([R])(C#C/C=C/C([R])([R])C#C)C#CC(C)/C=C\C=C/C=C\C#C</smiles>

$59 \mathrm{R}^{1}=\mathrm{H}, \mathrm{R}^{2}=\mathrm{OH}, \mathrm{R}^{3}=\mathrm{OH}, \mathrm{R}^{4}=\mathrm{H}, \mathrm{n}=14$; petrocortyne $\mathrm{B}$ $73 \mathrm{R}^{1}=\mathrm{OH}, \mathrm{R}^{2}=\mathrm{H}, \mathrm{R}^{3}=\mathrm{H}, \mathrm{R}^{4}=\mathrm{OH}, \mathrm{n}=14$

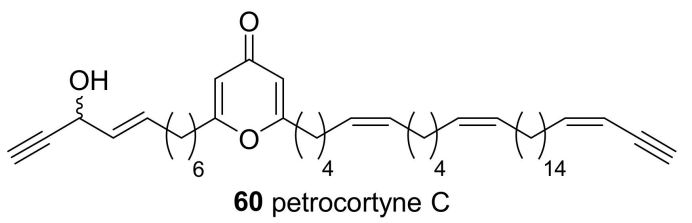<smiles>[R]C([R])(C#C)/C=C/C(C)C#CC(O)C#CC(C)C=CC(C)C(C)/C=C\C(C)C</smiles>

$63 \mathrm{R}^{1}=\mathrm{H}, \mathrm{R}^{2}=\mathrm{OH}$; petrocortyne $\mathrm{F}$ $75 \mathrm{R}^{1}=\mathrm{OH}, \mathrm{R}^{2}=\mathrm{H}$

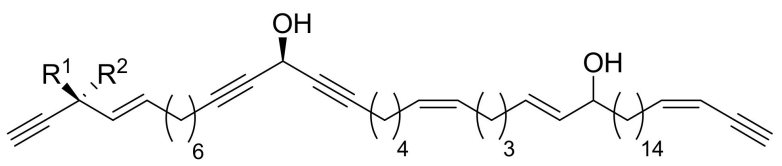

$65 \mathrm{R}^{1}=\mathrm{H}, \mathrm{R}^{2}=\mathrm{OH}$; petrocortyne $\mathrm{H}$ $77 \mathrm{R}^{1}=\mathrm{OH}, \mathrm{R}^{2}=\mathrm{H}$<smiles>C#C/C=C\C(C)C=CC(=O)C=CC(C)C#CC(O)C#CC(C)C</smiles>

70 petrotetrayndiol C<smiles>C#CC(C)C=CC(C)C=CC(C)C#CC(O)C#CC(C)C(C)C#C</smiles><smiles>C#CC=CC=CC=CC=CC(O)C#CC(C)C=CC(O)C#C</smiles>

82 petrotriyndiol $A$

Figure 4. Petrocortyne derivatives isolated from Korean Petrosia sponges.

Derivatives of the above mentioned petrocortynes appear in the several reports regarding Korean Petrosia sponges. Isolation of (3S, 14S)-petrocortyne A (66), nor- $(3 S, 14 S)$ petrocortyne A (67), and petrotetrayndiols A-C (68-70) from the Petrosia inhabiting the same area was later reported [48,49]. Additional petrocortynes (71-77) and petrotetrayndiol derivatives (78-83) were isolated and reported by another research group [50,51]. Most of these compounds showed high cytotoxicity against several human solid tumor cell lines.

Seo et al. reported the isolation of C30 polyacetylenes analogous to petrosynol (26) from the above mentioned Petrosia sp. collected near Keomun Island (Figure 5) and named these petrosiacetylenes A-D (84-87) [46]. Compounds 86 and 87 are mixtures of diastereomers at $\mathrm{C}-28$. In the same year, another research group reported the compounds of the same type (dideoxypetrosynols A-D) along with petrosynol (26) and duryne (37) [52]. Dideoxypetrosynols A-C later turned out to be the same compounds as petrosiacetylenes 
A (84), C (86), and B (85), respectively, although the diasteromeric ratio of petrosiacetylene C $(28 S: 28 R=60: 40)$ and dideoxypetrosynol B $(28 S: 28 R=50: 50)$ were slightly different. Dideoxypetrosynol D (88) was also a mixture of $28 S$ and $28 R$ diastereomers. Additional dideoxypetrosynols $(\mathbf{8 9}, \mathbf{9 0})$ were reported, although the positions of multiple bonds and the stereochemistry have not been revealed [48]. Petrosiacetylene E (91) was isolated and its structure was completely elucidated [53]. Compared to analogous petrosiacetylenes A (84) and C (86), compound 91 showed three times higher cytotoxicity against a panel of human cancer cell lines, which emphasized the importance of the hydroxygroup at C-15.<smiles>C#CCC=CCC#CCC#CCC=CC(O)C#C</smiles>

84 petrosiacetylene A, dideoxypetrosynol A<smiles>C#CC(O)C=CCC#CCC=CC#CC(O)C(C)C#C</smiles>

88 dideoxypetrosynol $D$

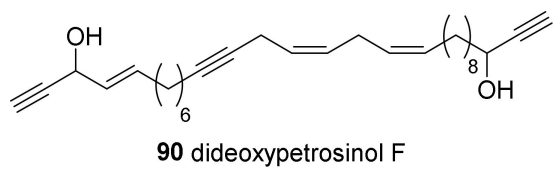

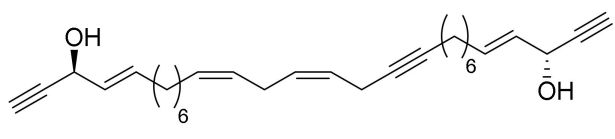

85 petrosiacetylene B, dideoxypetrosynol C<smiles>C#CCCCCC#CCCCCC=CC(O)C#C</smiles>

87 petrosiacetylene $D(28 S ; 28 R=80: 20)$<smiles>C#C/C=C\C(O)/C=C/C/C=C/C=C/C=C/C(O)C#C</smiles>

$89 m+n=15 ;$ dideoxypetrosinol $E$

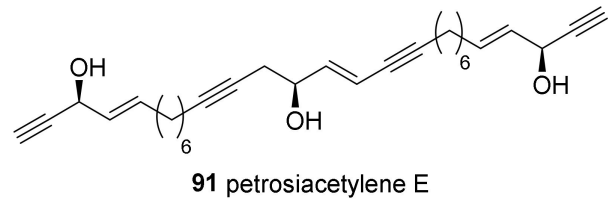

Figure 5. Petrosiacetylenes isolated from Korean Petrosia sponges.

Novel enol ether glycerides (92-97) were isolated from the above mentioned Petrosia sponge collected near Keomun Island, along with analogous raspailynes and isoraspailynes (98-101) which have previously been isolated from the sponges Raspailia pumila and Raspailia ramosa (Figure 6) [54,55]. In the measurement of cytotoxicity against a human leukemia cell line (K562), the yne-diene derivatives (92-94) exhibited weak activity $\left(\mathrm{LC}_{50}\right.$ 9.2, 57.0, and $29.0 \mu \mathrm{g} / \mathrm{mL}$, respectively), while the derivatives 95-97, possessing the yne-ene moiety, were not active. The carboxylate (102), which has an acetylenic alcohol moiety and a linear $\mathrm{C} 12$ carbon chain, was also reported in the same paper. This is reminiscent of petroformynes $(23,24)$ and petroformynic acid $(25)$, which were isolated from Mediterranean P. ficiformis.

\subsubsection{Polyacetylenes Isolated from Tropical Petrosia Sponges}

Several polyacetylenes have been isolated from tropical Petrosia sponges, although not as many as those from their counterparts in temperate regions. These compounds can be categorized into two groups: one comprised of compounds bearing a diynol group and the other comprised of enyne carboxylates.

Alcohols with 2,4-diyne (the first group) were isolated from the Okinawan sponges of Petrosia genus (Figure 7). Strongylodiols A-J (103-112) were isolated from an Okinawan Strongylophora sponge that was later revised as Petrosia [56,57]. These compounds were isolated as mixtures of enantiomers at C-6, which were resolved by modified Mosher's method. 


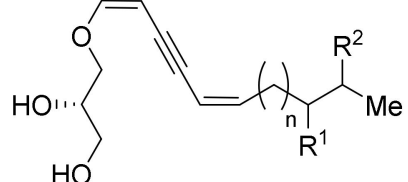

$92 \mathrm{R}^{1}=\mathrm{H}, \mathrm{R}^{2}=\mathrm{H}, \mathrm{n}=3$; petroraspailyne $\mathrm{A} 1$

$93 R^{1}=H, R^{2}=M e, n=3$; petroraspailyne $A 2$

$94 R^{1}=M e, R^{2}=H, n=5$; petroraspailyne $A 3$

$98 \mathrm{R}^{1}=\mathrm{H}, \mathrm{R}^{2}=\mathrm{H}, \mathrm{n}=5$; raspailyne $\mathrm{B} 1$

$99 R^{1}=H, R^{2}=H, n=4$; raspailyne $B 2$

$100 R^{1}=H, R^{2}=M e, n=5$; isoraspailyne $B$<smiles>C#C[C@H](O)/C=C/C(C)C(=O)OC</smiles>

102 petrynol

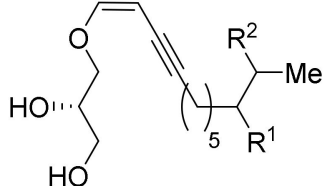

$95 \mathrm{R}^{1}=\mathrm{H}, \mathrm{R}^{2}=\mathrm{H}, \mathrm{n}=5$; petroraspailyne $\mathrm{B} 1$

$96 R^{1}=M e, R^{2}=M e, n=5$; petroraspailyne $B 2$

$97 \mathrm{R}^{1}=\mathrm{H}, \mathrm{R}^{2}=\mathrm{Me}, \mathrm{n}=5$; petroraspailyne $B 3$

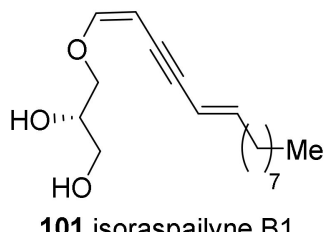

Figure 6. Polyacetylenic enol ether glycerides and carboxylates isolated from Korean Petrosia sponges.

Analogous triols, strongylotriols $(\mathbf{1 1 3}, \mathbf{1 1 4})$, and pellynols (115-117) were also isolated from an Okinawan Petrosia sponge [58]. The strongylotriols were found to be optically pure, whereas the pellynols were diasteromeric mixtures at C-6. The strongylotriols and pellynols exhibited different levels of cytotoxicity against $\mathrm{HeLa}$ and $\mathrm{K} 562$ cell lines; strongylotriols A and $\mathrm{B}(\mathbf{1 1 3}, \mathbf{1 1 4})$ exhibited $\mathrm{IC}_{50}$ values of $11.3-18.1 \mu \mathrm{M}$, and pellynols $\mathrm{A}, \mathrm{B}$ and $\mathrm{J}(\mathbf{1 1 5}-\mathbf{1 1 7})$ exhibited $\mathrm{IC}_{50}$ values of $0.5-0.6 \mu \mathrm{M}$.

The tetraol derivatives, petrosiols (118-122), were isolated along with strongylodiols $C$ and D $(105,106)$ from an extract of the Okinawan sponge P. strongylata [59]. The stereochemistry of the petrosiols was determined by derivatizing petrosiol $C(\mathbf{1 2 0}) ; 120$ was hydrogenated using a Pt catalyst to provide the fully saturated derivative, then the stereochemistry of the product was assigned by comparing its ${ }^{1} \mathrm{H}$ NMR to those of the four stereoisomers of 1,2,6,7-decanetetraol provided in Kishi's Universal NMR databases [60]. Petrosiols (118-122) induced nerve growth factor-like neuronal differentiation of PC12 cells, which suggested the importance of the rare 2,4-diyne-1,6,7,8-tetraol fragment in neurotrophic activity.

The same type of acetylenic alcohols (123-131) were additionally isolated from an Okinawan Petrosia sp. [61]. In the regarding report, it is described that the position of the central double bonds in compounds was revealed by chemical transformation-the oxidative cleavage of the olefin, followed by the transformation of resulting aldehyde into the corresponding 2,4-dinitrophenylhydrazone. The analysis of the HRMS and ${ }^{13} \mathrm{C}-\mathrm{NMR}$ spectral data of each resulting hydrazones clarified the position of the central double bonds in 123-131.

Additional 2,4-diyn-1-ols were also isolated from Petrosia sponges growing in other tropical areas. Durissimols A and B (132-133) were isolated from P. durissima collected in Taiwan, along with the previously reported derivatives $(37,134-136)$ isolated from Reniera fulva [62]. Among the compounds isolated, duryne (37) and durissimol B (133) exhibited potent cytotoxicity against human gastric cancer cells (NUGC). Pellynol derivatives (115, 137-140) were isolated from a Petrosia sp. collected in American Samoa [63].

Enyne carboxylates (141-144), comprising the second group of petrosiacetylenes in tropical Petrosia, were isolated from the sponge mentioned directly above (Figure 8) [63]. 
<smiles>[R]C(C)N=CC=CC(O)C#CC#CCO</smiles>

$103 \mathrm{R}=\mathrm{H}$; strongylodiol A $(6 R: 6 S=91: 9)$ $105 \mathrm{R}=\mathrm{Me}$; strongylodiol $\mathrm{C}(6 R: 6 S=84: 16)$

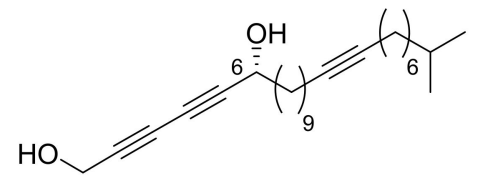

$104 \mathrm{R}=\mathrm{H}$; strongylodiol $\mathrm{B}(6 R: 6 S=97: 3)$ $106 \mathrm{R}=\mathrm{Me}$; strongylodiol $\mathrm{D}(6 R: 6 S=95: 5)$<smiles>C#CC=CC=CC=CC(O)C#CC#CCO</smiles>

107 strongylodiol $\mathrm{E}(6 R: 6 S=61: 39)$

$1087 E$; strongylodiol $\mathrm{F}(6 R: 6 S=80: 20)$<smiles>CC(C)C(C)C(C)C(O)C#CC#CCO</smiles>

109 strongylodiol G

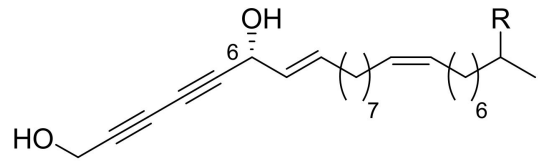

$110 \mathrm{R}=\mathrm{H}$; strongylodiol $\mathrm{H}(6 R: 6 \mathrm{~S}=94: 6)$ $111 \mathrm{R}=\mathrm{Me}$; strongylodiol I $(6 R: 6 S=97: 3)$<smiles>C#CC=CC(C)(C)C#CC(C)(C)C(C)(C)C#CC#CCO</smiles>

112 strongylodiol $\mathrm{J}(6 R: 6 S=96: 4)$<smiles>[R]C(C)C#CC(O)C(C)C(C)C#CC#CCO</smiles>

$113 \mathrm{R}=\mathrm{H}$; strongylotriol $\mathrm{A}$ $114 \mathrm{R}=\mathrm{Me}$; strongylotriol $\mathrm{B}$<smiles>C#CC(O)C=CC=CC(C)C(C)C#CC#CCO</smiles>

$115 \mathrm{n}=11$; pellynol $\mathrm{A}$ $116 \mathrm{n}=10$; pellynol $B$ $117 \mathrm{n}=9$; pellynol $\mathrm{J}$<smiles>[R]C(C)C(=O)/C=C\C[C@@H](O)[C@@H](O)[C@H](O)C#CC#CCO</smiles>

$118 \mathrm{R}=\mathrm{H}, \mathrm{n}=6$; petrosiol $\mathrm{A}$ $119 \mathrm{R}=\mathrm{Me}, \mathrm{n}=6$; petrosiol $\mathrm{B}$ $121 \mathrm{R}=\mathrm{H}, \mathrm{n}=7$; petrosiol $\mathrm{D}$<smiles>C#C/C=C\C=C/CC(O)C(O)C(O)C#CC#CCO</smiles>

120 petrosiol C<smiles>CC(C)C(O)C(O)C(O)C(O)C#CC#CCO</smiles>

122 petrosiol E<smiles>[R]C(C)C=CC#CC#CCO</smiles>

$123 \mathrm{R}=\mathrm{H}, \mathrm{n}=6$

$124 \mathrm{R}=\mathrm{Me}, \mathrm{n}=6$

$125 \mathrm{R}=\mathrm{Me}, \mathrm{n}=4$<smiles>C#CC=CC=CC#CC#CCO</smiles>

$126 \mathrm{~m}=10, \mathrm{n}=10$ $127 \mathrm{~m}=12, \mathrm{n}=10$<smiles>OCC#CC#CC=CC=CCCCCO</smiles>

128<smiles>CC(C)N=CC=CC=CC#CCCO</smiles>

129<smiles>C#C/C=C/N=CC=C(C)C(C)(C)O</smiles>

130<smiles>C#CC#CCO</smiles>

131<smiles>CC(C)CCC#CC#CCO</smiles>

132 durissimol $A$<smiles>C#CC(C)C=CC#CC#CC#CCO</smiles>

133 durissimol $B$<smiles>OCC#CC=CC=CC=CCO</smiles>

134 reneirin 2 ho<smiles>C#CC(O)C=CC=CC#CC(O)C#CC#CCO</smiles>

136 melyne C<smiles>C#CC(O)C=CCC#CC=CC(O)C#CC#CCO</smiles><smiles>C#CC(O)C=CCC#CCC=C(O)C#CC#CCO</smiles>

$139 m+n=18 ;$ pellynol $\mathrm{F}$

Figure 7. 2,4-Diyn-1-ols isolated from tropical Petrosia sponges. 
<smiles>C#C[C@H](O)/C=C/C(C)(C)/C=C\C(C)/C=C\C#CC(=O)O</smiles>

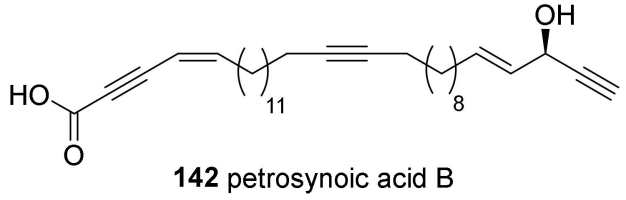<smiles>C#CC(O)/C=C/C#C/C=C\C(C)=C/C=C\C#CC(=O)O</smiles><smiles>C#CC(O)C=CCC=CC(O)C(C)(C)C=CC#CC(=O)O</smiles><smiles>C#C[C@H](O)/C=C/C(C)C(C)/C=C\C#CC(=O)O</smiles>

Figure 8. Enyne carboxylates isolated from tropical Petrosia sponges.

In the measurement of cytotoxicity against three human cancer cell lines (A2058, H522-T1, H460) and one non-proliferating human fibroblast (IMR-90), all nine compounds $(\mathbf{1 1 5}, \mathbf{1 3 7}-\mathbf{1 4 4})$ were active against human cancer cell lines with $\mathrm{IC}_{50}$ values ranging of 0.4-2.7 $\mu \mathrm{M}$; however, all compounds were also similarly potent against the IMR-90 cells.

In an earlier study on tropical Petrosia sp., aztèquynols A and B $(\mathbf{1 4 5}, \mathbf{1 4 6})$ were isolated from the cytotoxic extract of a Petrosia sp. collected in New Caledonia [64]. The structures were assigned by NMR spectroscopy, FAB MS/MS, and chemical transformation; however, neither of the compounds accounted for the cytotoxicity of the sponge extract against KB tumor cell lines (less than $20 \%$ cytotoxicity at $10 \mu \mathrm{g} / \mathrm{mL}$ ).

\subsection{Terpenoids and Related Compounds}

\subsubsection{Sterols Isolated from Tropical Petrosia Sponges}

Unique sterols with an extended side chain have been isolated from Petrosia sponges. Sterols were isolated from tropical Petrosia more frequently. There are 12 papers reporting the isolation of 40 sterols from tropical Petrosia sp., while four papers regarding five sterols from temperate counterparts.

The first Petrosia-derived sterol was isolated from Indo-Pacific S. durissima [65] (Figure 9). The structure of this sterol (147), named strongylosterol, was completely resolved later by chemical synthesis [66]. Subsequently, additional minor sterols (148-151) were isolated from the extract of the same species, and the structures were elucidated by comparing spectroscopic data with those obtained for synthesized derivatives $[67,68]$.

Oxygenated cholestane derivatives were isolated from a Petrosia sp. collected off the Saudi Arabian Red Sea coast $\left(21^{\circ}\right.$ N) [69]. The compounds in this series-containing a tetracyclic skeleton of 3,7,9-trihydroxycholastane (152) - are isolated in the form of oxidized derivatives, i.e., formate (153), epoxide (154), peroxide (155), and diene (156). Compounds with the reduced C-7 (157) or a carbonyl group at C-17 (158) were also isolated. For these compounds, cytotoxicity against human hepatocellular carcinoma (HepG2) and human breast adenocarcinoma (MCF7) was measured; however, none of the compounds showed a meaningful level of activity. 

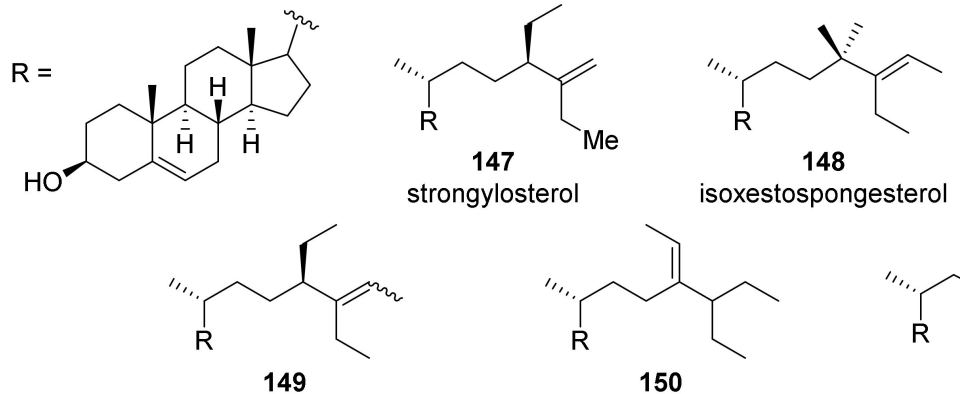

26-methylstrongylosterol

28-methylxestosterol<smiles>[R]C(C)CCC(C)(C)C(=C)CC</smiles>

durissimasterol

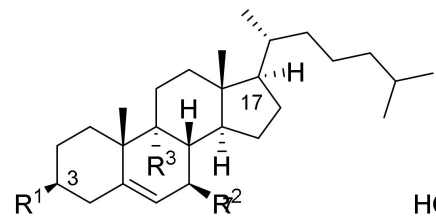

$152 \mathrm{R}^{1}=\mathrm{OH}, \mathrm{R}^{2}=\mathrm{OH}, \mathrm{R}^{3}=\mathrm{OH}$

$153 \mathrm{R}^{1}=\mathrm{OCOH}, \mathrm{R}^{2}=\mathrm{Me}, \mathrm{R}^{3}=\mathrm{H}$<smiles>CC(C)CCC[C@H](C)[C@H]1CC[C@H]2C3=CC=C4CC(O)CC[C@]4(C)[C@H]3CC[C@]21C</smiles><smiles>CC(C)CCC[C@H](C)[C@H]1CC[C@H]2C3CC=C4CC(O)CC[C@]4(C)C3CC[C@]21C</smiles><smiles>CC12CC[C@H]3C(CC=C4CC(O)CC[C@]43C)C1CCC2=O</smiles>

Figure 9. Sterols isolated from tropical Petrosia sponges.

The C29-steroids with a cyclopropane ring at C-25-C-27 (159-174) were isolated from the Thai sponge of Petrosia genus (Figure 10) [70]. Based on the assumption that compounds with 3-dimethyl ketal functionality $(161,162,169,170,172)$ might have been artificially formed during isolation and purification, compounds with a carbonyl group at C-3 (165, 173) were subjected to conditions similar to those during isolation and purification. No change in the thin layer chromatography analyses was observed, even after one month, suggesting that isolated dimethyl ketal derivatives occur naturally. Compounds-except for 162, 167 and 169-were evaluated for cytotoxicity against six human cancer cell lines and a normal cell line. Compound 173 was the most potent, with $\mathrm{IC}_{50}$ values of 7.1 and 6.1 $\mu \mathrm{M}$ against HepG2 and HeLa cell lines, respectively. All the other compounds exhibited minimal to weak cytotoxicity, with $\mathrm{IC}_{50}$ values in the range of $11.2-103.5 \mu \mathrm{M}$.

Xetobergsterol A (175) and contignasterol (176), which contain a highly oxygenated cyclic skeleton and a ketone moiety at C-15, were isolated from $P$. cf. contignata and $P$. contignata Thiele, respectively [71,72]. Both compounds contain a $14 \beta$ hydrogen, which is very rare in naturally occurring steroids, although steroids with a $14 \beta$-hydroxyl functionality (i.e., digitoxin) are well-known in nature.

Three pregnane derivatives (177-179) bearing the unique 2,10-carbolactone moieties were isolated from Strongylophora (Petrosia) sp. collected at Puako, Hawaii [73]. The structures were assigned based on spectroscopic data and confirmed by X-ray crystallography of 177. Compounds $\mathbf{1 7 8}$ showed marginal cytotoxicity against human epidermoid carcinoma (KB) and human colorectal adenocarcinoma (LoVo) cell lines with MIC values of 1.0 and $5.0 \mu \mathrm{g} / \mathrm{mL}$, respectively, while compound 177 and 179 showed no activity. 


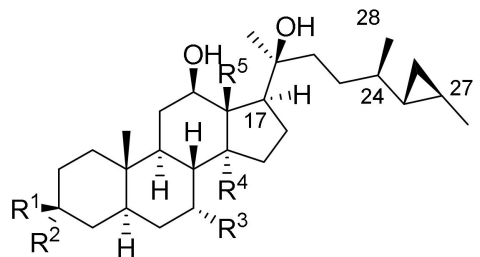

$159 \mathrm{R}^{1}=\mathrm{H}, \mathrm{R}^{2}=\mathrm{OH}, \mathrm{R}^{3}=\mathrm{OH}, \mathrm{R}^{4}=\mathrm{H}, \mathrm{R}^{5}=\mathrm{Me}$ $160 \mathrm{R}^{1}=\mathrm{H}, \mathrm{R}^{2}=\mathrm{OH}, \mathrm{R}^{3}=\mathrm{H}, \mathrm{R}^{4}=\mathrm{OH}, \mathrm{R}^{5}=\mathrm{Me}$ $161 \mathrm{R}^{1}=\mathrm{OMe}, \mathrm{R}^{2}=\mathrm{OMe}, \mathrm{R}^{3}=\mathrm{OH}, \mathrm{R}^{4}=\mathrm{H}, \mathrm{R}^{5}=\mathrm{Me}$;

$162 \mathrm{R}^{1}=\mathrm{OMe}, \mathrm{R}^{2}=\mathrm{OMe}, \mathrm{R}^{3}=\mathrm{H}, \mathrm{R}^{4}=\mathrm{H}, \mathrm{R}^{5}=\mathrm{CH}_{2} \mathrm{OH}$ $163 \mathrm{R}^{1}=\mathrm{H}, \mathrm{R}^{2}=\mathrm{OH}, \mathrm{R}^{3}=\mathrm{H}, \mathrm{R}^{4}=\mathrm{H}, \mathrm{R}^{5}=\mathrm{Me}$ $164 R^{1}, R^{2}=O, R^{3}=H, R^{4}=H, R^{5}=M e$ $165 R^{1}, R^{2}=O, R^{3}=O H, R^{4}=H, R^{5}=M e$<smiles>CC(C)C/C=C/[C@@](C)(O)[C@H]1CC[C@H]2[C@H]3[C@H](C[C@H](O)[C@]21C)[C@@]1(C)CCC(=O)C[C@@H]1C[C@H]3O</smiles>

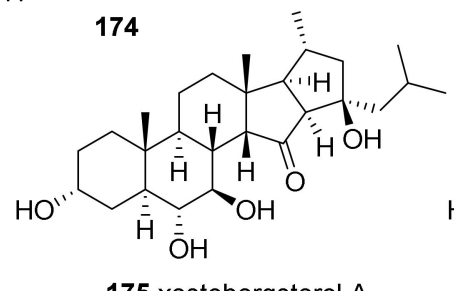

175 xestobergsterol A

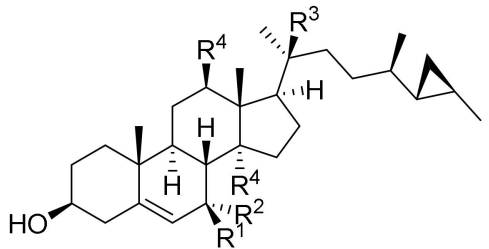

$166 \mathrm{R}^{1}=\mathrm{H}, \mathrm{R}^{2}=\mathrm{OH}, \mathrm{R}^{3}=\mathrm{OH}, \mathrm{R}^{4}=\mathrm{OH}$ $167 \mathrm{R}^{1}=\mathrm{H}, \mathrm{R}^{2}=\mathrm{H}, \mathrm{R}^{3}=\mathrm{H}, \mathrm{R}^{4}=\mathrm{H}$ $168 R^{1}, R^{2}=O, R^{3}=H, R^{4}=H$

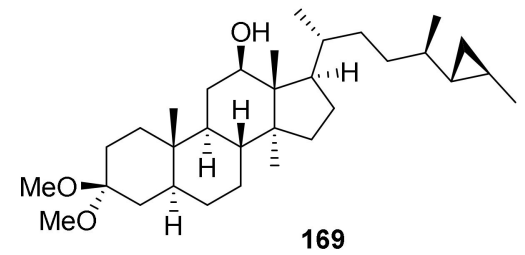

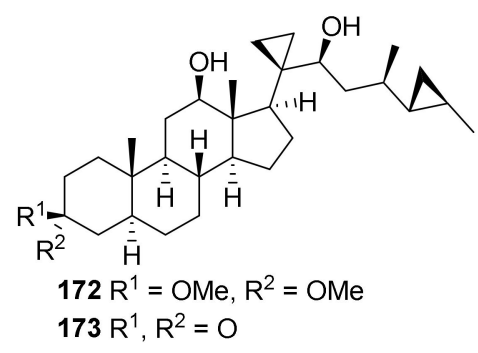

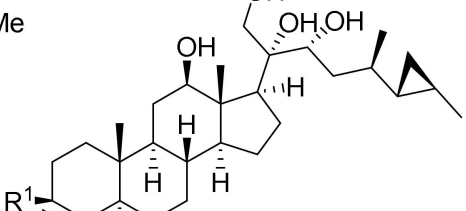

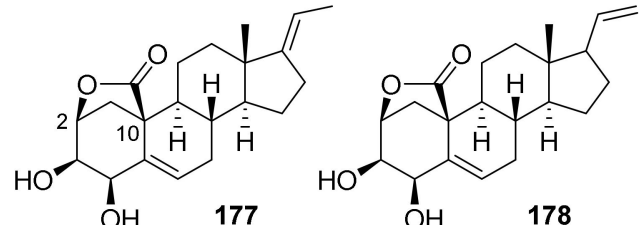
$170 \mathrm{R}^{1}=\mathrm{OMe}, \mathrm{R}^{2}=\mathrm{OMe}$ $171 R^{1}, R^{2}=0$

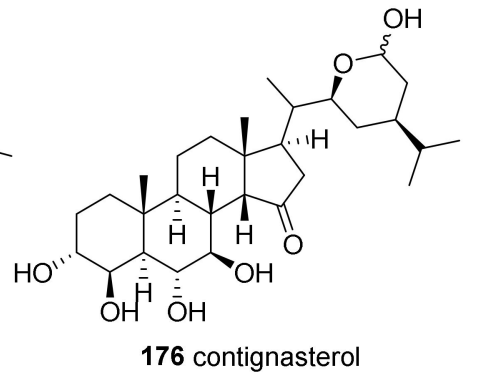

177<smiles>CC(=O)C1=CC[C@H]2[C@@H]3CC=C4[C@@H](O)[C@@H](O)[C@@H]5CC4(C(=O)O5)[C@H]3CC[C@]12C</smiles>

Figure 10. Polyhydroxysterols isolated from tropical Petrosia sponges.

Sulfated sterols with an ortho ester (orthoesterols A-C, 180-182) were isolated from the extract of P. weinbergi collected in the Bahamas (Figure 11) [74]. The compounds were isolated through the bioassay-guided separation of the extract, which showed activity against feline leukemia virus (FELV), mouse influenza virus (PR8), and mouse coronavirus (A59) and all three (180-182) showed activities against FELV and PR8.
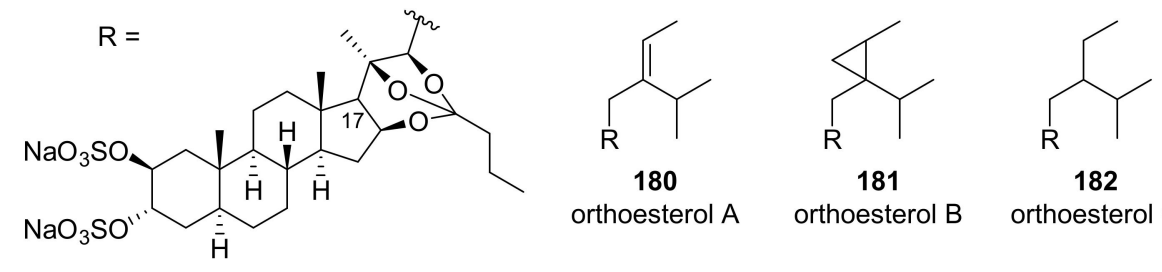

orthoesterol A

orthoesterol B orthoesterol C

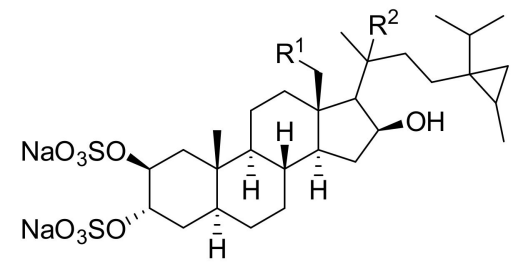

$183 \mathrm{R}^{1}=\mathrm{H}, \mathrm{R}^{2}=\mathrm{OH}$; weinbersterol $\mathrm{A}$ $184 \mathrm{R}^{1}=\mathrm{OH}, \mathrm{R}^{2}=\mathrm{H}$; weinbersterol $\mathrm{B}$

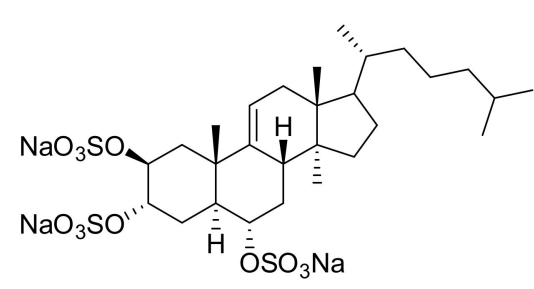

185 lembehsterol A

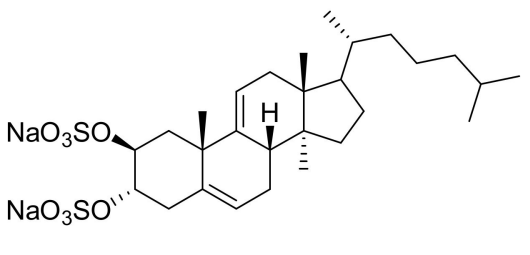

186 lembehsterol B

Figure 11. Sulfated sterols isolated from tropical Petrosia sponges. 
Weinbesterol A and B $(\mathbf{1 8 3}, \mathbf{1 8 4})$, sulfated tetrahydroxysteroids with a cyclopropanecontaining side chain, were isolated from the P. weinbergi collected in the Bahamas [75]. The structures were resolved using extensive NMR experiments, including 2D INADEQUATE, HMBC, HETCOR, COSY, and COLOC. Both were active against FELV $\left(\mathrm{EC}_{50}=4.0\right.$ and $5.2 \mu \mathrm{g} / \mathrm{mL}$, respectively), and 183 was active against $\mathrm{HIV}\left(\mathrm{EC}_{50}=1.0 \mu \mathrm{g} / \mathrm{mL}\right)$.

Lembehsterols A and B $(\mathbf{1 8 5}, \mathbf{1 8 6})$ were isolated from $P$. strongylata collected at Lembeh Island, Indonesia [76]. Both showed inhibitory activity against thymidine phosphorylase $\left(\mathrm{IC}_{50}=41.0\right.$ and $45.0 \mu \mathrm{M}$, respectively) which is related to angiogenesis in solid tumors. Desulfated derivatives obtained by the treatment of $\mathbf{1 8 5}$ with acid showed no inhibition at $230.0 \mu \mathrm{M}$, suggesting the importance of the sulfate group for the activity against thymidine phosphorylase.

\subsubsection{Sterols Isolated from Temperate Petrosia Sponges}

Sterols have rarely been isolated from Petrosia sponges in temperate regions. Only two species, P. ficiformis and S. corticata, were found to contain sterol compounds. All the isolated sterols from both contain cyclopropane in the branch at C-17 (Figure 12). Petrosterol (187), a steroid with a cyclopropane ring at C-25 and C-26, was isolated from $P$. ficiformis collected in the Bay of Naples, and its structure was confirmed by the X-ray crystallography of a synthesized p-bromobenzoate derivative [77,78]. Subsequent studies tracing the minor component of the same species resulted in the isolation of ficisterol (188) [79]. 7-Oxo and 7-hydroxy derivatives of petrosterols $(\mathbf{1 8 9}, \mathbf{1 9 0})$ were isolated from S. corticata collected off the coast of Tokushima $\left(33^{\circ} \mathrm{N}\right)$ [80] along with petrosterol (187) and dihydrocalysterol (191). Compound 191 has been isolated from the sponge Calyx niceaensis, previously [81]. The biological activity of the petrosterol analogs (187-191) have not been reported yet.

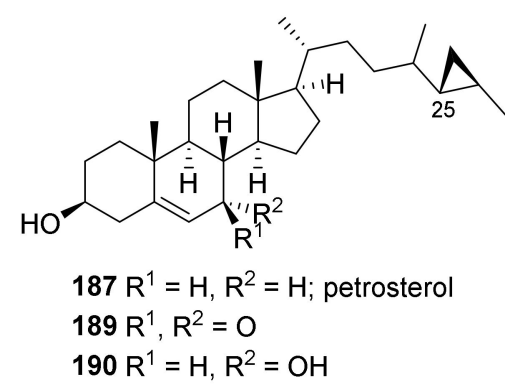

Figure 12. Sterols isolated from temperate Petrosia sponges.

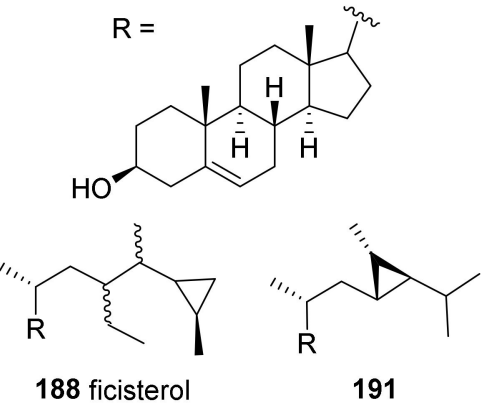

191

\subsubsection{Meroterpeonids Isolated from Tropical Petrosia Sponges}

Meroterpenoids are a group of compounds that are partially derived from the terpenoid biosynthetic pathway. In the marine environment, meroterpenoids have been isolated most frequently from brown algae and microorganisms, but another important source is marine invertebrates, such as sponges and tunicates [82]. All the meroterpenoids isolated from Petrosia sponges are from sponges collected in tropical areas.

Strongylophorines, which are meroditerpenoids with a quinol or a quinone moiety, are the most abundant metroditerpenoids in Petrosia sponges (Figure 13). Initially, strongylophorines 1-3 (192-194) were isolated from S. durissima collected in Papua New Guinea and identified based on their spectral properties, chemical synthesis, and X-ray diffraction analysis [83]. Five additional analogs, strongylophorines 4-8 (195-199), were isolated from the same species collected in the Philippines [84]. These compounds (192-199) exhibited mild antimicrobial activity against Bacillus subtilis and Staphylococcus aureus, with the two quinones $(\mathbf{1 9 7}, \mathbf{1 9 8})$ showing the greatest inhibition. Strongylophorines 9,11 and 12 (200-202) were isolated from the same species inhabiting Taiwanese water, along with strongylophorine 1-3 (192-194), and 5 (196) [62,85]. 


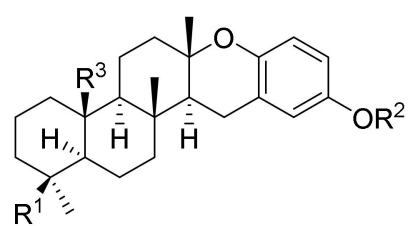

$192 \mathrm{R}^{1}=\mathrm{CO}_{2} \mathrm{H}, \mathrm{R}^{2}=\mathrm{Me}, \mathrm{R}^{3}=\mathrm{Me}$; strongylophorine 1 $194 \mathrm{R}^{1}=\mathrm{CO}_{2} \mathrm{H}, \mathrm{R}^{2}=\mathrm{H}, \mathrm{R}^{3}=\mathrm{Me}$; strongylophorine 3

$195 \mathrm{R}^{1}=\mathrm{COH}, \mathrm{R}^{2}=\mathrm{H}, \mathrm{R}^{3}=\mathrm{Me}$; strongylophorine 4

$196 \mathrm{R}^{1}=\mathrm{CH}_{2} \mathrm{OH}, \mathrm{R}^{2}=\mathrm{H}, \mathrm{R}^{3}=\mathrm{Me}$; strongylophorine 5

$202 \mathrm{R}^{1}=\mathrm{CO}_{2} \mathrm{H}, \mathrm{R}^{2}=\mathrm{COMe}, \mathrm{R}^{3}=\mathrm{Me}$; strongylophorine 12

$203 R^{1}=M e, R^{2}=H, R^{3}=M e$; strongylophorine 22

$204 \mathrm{R}^{1}=\mathrm{Me}, \mathrm{R}^{2}=\mathrm{H}, \mathrm{R}^{3}=\mathrm{CH}_{2} \mathrm{OH}$; strongylophorine 23

$205 R^{1}=\mathrm{Me}, \mathrm{R}^{2}=\mathrm{H}, \mathrm{R}^{3}=\mathrm{COH}$; strongylophorine 24

$206 \mathrm{R}^{1}=\mathrm{CH}_{2} \mathrm{OH}, \mathrm{R}^{2}=\mathrm{H}, \mathrm{R}^{3}=\mathrm{CH}_{2} \mathrm{OH}$; strongylophorine 25

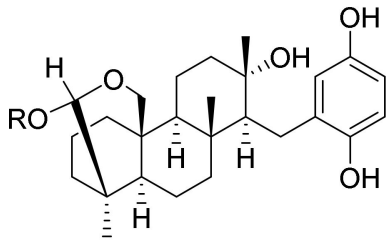

$207 \mathrm{R}=\mathrm{H}, 26 R$; strongylophorine 13 $208 \mathrm{R}=\mathrm{H}, 26 \mathrm{~S}$; strongylophorine 14 $214 \mathrm{R}=\mathrm{Et}, 26 S$

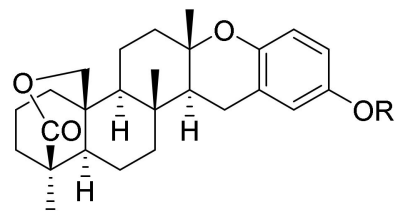

$193 \mathrm{R}=\mathrm{H}$; strongylophorine 2 $200 \mathrm{R}=\mathrm{Me} ;$ strongylophorine 9 $201 \mathrm{R}=\mathrm{COMe}$; strongylophorine 11

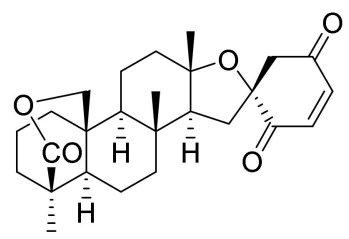

198 strongylophorine 7

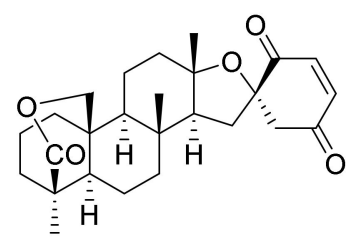

197 strongylophorine 6

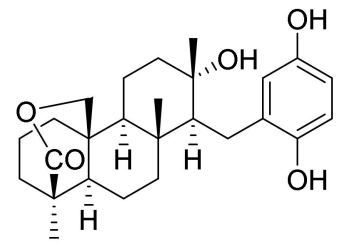

199 strongylophorine 8

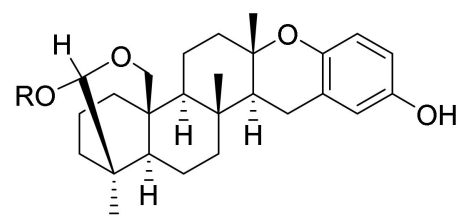

$209 \mathrm{R}=\mathrm{H}, 26 \mathrm{R}$; strongylophorine 15 $210 \mathrm{R}=\mathrm{H}, 26 \mathrm{~S}$; strongylophorine 16 $215 \mathrm{R}=\mathrm{Me}, 26 \mathrm{~S}$

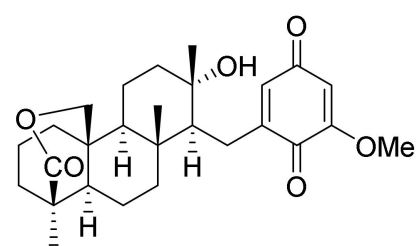

216 strongylophorine 26

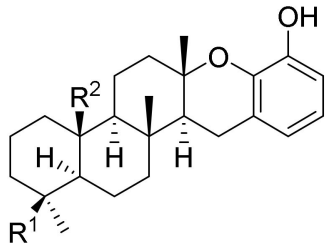

$211 \mathrm{R}^{1}=\mathrm{CH}_{2} \mathrm{OH}, \mathrm{R}^{2}=\mathrm{CH}_{2} \mathrm{OH}$; strongylophorine 17 $212 \mathrm{R}^{1}=\mathrm{Me}, \mathrm{R}^{2}=\mathrm{CH}_{2} \mathrm{OH}$; strongylophorine 18 $213 \mathrm{R}^{1}=\mathrm{COH}, \mathrm{R}^{2}=\mathrm{Me}$; strongylophorine 19

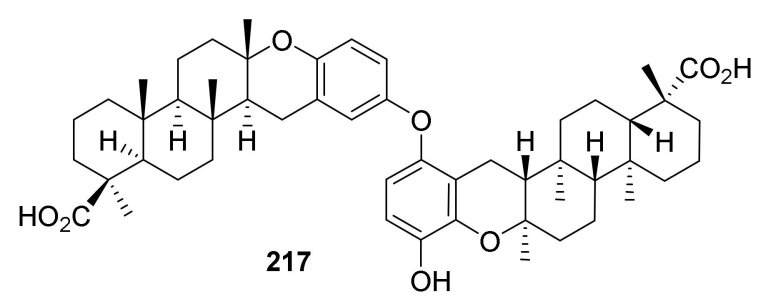

Figure 13. Strongylophorine derivatives isolated from tropical Petrosia sponges.

Eighteen strongylophorines (192-195, 199, 203-215) were isolated from Okinawan Petrosia sponges. From P. corticata, strongylophorines 1-4 (192-195), 8 (199), 15-16 (209, 210), and 22-24 (203-205) were isolated and structures were identified by spectroscopic analysis and chemical transformation [86]. Among these compounds, strongylopohrine 22 (203) showed moderate cytotoxicity against HeLa cells with an $\mathrm{IC}_{50}$ value of $26.6 \mu \mathrm{M}$. Eleven derivatives-strongylophorines 2-4 (193-195), 8 (199), 13-19 (207-213)—were isolated from S. strongylata [87]. Except for strongylophorine 4 (195), all compounds inhibited the maturation of starfish oocytes with $\mathrm{IC}_{50}$ values of 1.1-37.6 $\mu \mathrm{M}$. The same species inhabiting in the same area were revisited after 10 years, which resulted in the isolation of additional analogs, 214 and 215, the acetal derivatives of strongylophorines [88]. In this study, the inhibitory activity of all the obtained strongylophorines $(193,194,199,209,211$, 214, 215) was measured against protein tyrosine phosphatase 1B (PTP1B), which plays a key role in the negative regulation of the insulin and leptin signaling pathways. Most of the compounds showed activity with 214 and 215 being the most potent $\left(\mathrm{IC}_{50} 8.7\right.$ and $8.5 \mu \mathrm{M}$, respectively).

Strongylophorines, which are the same as the above mentioned compounds from Okinawan Petrosia, were isolated from P. corticata collected in North Sulawesi, Indonesia [89]. In this study, the inhibitory activities of the isolated compounds (193-195, 199, $\mathbf{2 0 3}, \mathbf{2 0 7}, \mathbf{2 0 8}, \mathbf{2 1 4}, \mathbf{2 1 5}$ ) were tested against the chymotrypsin-like activity of proteasome. The mixture of diasteromeric hemiacetals (strongylophorines 13,$14 ; \mathbf{2 0 7}, \mathbf{2 0 8}$ ) were the 
most potent $\left(\mathrm{IC}_{50} 2.1 \mu \mathrm{M}\right)$, and the acetal compounds $(214,215)$ were slightly less potent $\left(\mathrm{IC}_{50} 9.3\right.$ and $6.6 \mu \mathrm{M}$, respectively), while the analogous lactone (193) showed no activity at $100 \mu \mathrm{M}$. Compounds 194, 195, and 203-bearing a carboxylate, an aldehyde, and a methyl group at C-4, respectively-showed the activities decreased in the same order $\left(\mathrm{IC}_{50} 9.5\right.$, 19.0, $100.0 \mu \mathrm{M}$, respectively).

Strongylophorine 26 (216) was isolated from the $P$. corticata collected in Papua New Guinea, along with strongylophorine 8 (199) [90]. Compound 216 exhibited an IC $_{50}$ value of approximately $1.0 \mu \mathrm{g} / \mathrm{mL}$ in the anti-invasion assay using MDA-231 cells, while 199 showed considerably less potency $\left(\mathrm{IC}_{50}, \sim 7.0 \mu \mathrm{g} / \mathrm{mL}\right)$.

A dimeric strongylophorine (217), composed of two equivalents of strongylophorine 3 (194), was isolated from a Philippine marine sponge of the genus Strongylophora (Petrosia), along with strongylophorines 2-4 (193-195) [91]. In this study, compounds 194 and 195 showed marginal activity against Micrococcus luteus and Salmonella typhi, respectively. Compound 194 was also active against the phytopathogenic fungus Cladosporium cucumerinum and the neonate larvae of the polyphagous insect pest Spodoptera littoralis $\left(\mathrm{EC}_{50} 69.0 \mu \mathrm{g} / \mathrm{mL}\right)$. Compound 217 was the most active in the brine shrimp lethality assay, with an $\mathrm{LC}_{50}$ value of $10.5 \mathrm{~g} / \mathrm{mL}$.

Pentacyclic quinones with a furan moiety make up another group of meroditerpenoids from Petrosia sponges (Figure 14). Halenaquinone (218), xestoquinone (219), and adociaquinones $(\mathbf{2 2 0}, \mathbf{2 2 1})$ are representatives of petacyclic quinones, originally isolated from sponges of the genus Xestospongia [92,93] or Adocia [94] (Schmitz and Bloor 1988).<smiles>[R]c1oc2c3c1C([R])CCC3c1cc3c(cc1C2=O)C(=O)C=CC3=O</smiles>

$218 R^{1}, R^{2}=O, R^{3}=H$; halenaquinone

$222 \mathrm{R}^{1}=\mathrm{OH}, \mathrm{R}^{2}=\mathrm{H}, \mathrm{R}^{3}=\mathrm{H}$; $223 \mathrm{R}^{1}=\mathrm{H}, \mathrm{R}^{2}=\mathrm{H}, \mathrm{R}^{3}=\mathrm{CHOHMe}$; $224 \mathrm{R}^{1}=\mathrm{H}, \mathrm{R}^{2}=\mathrm{H}, \mathrm{R}^{3}=\mathrm{CH}_{2} \mathrm{CH}_{2} \mathrm{OH}$<smiles></smiles>

$219 \mathrm{R}^{1}=\mathrm{H}, \mathrm{R}^{2}=\mathrm{H}$; xestoquinone $237 \mathrm{R}^{1}=\mathrm{H}, \mathrm{R}^{2}=\mathrm{CH}_{2} \mathrm{OH}$ $238 \mathrm{R}^{1}=\mathrm{CO}_{2} \mathrm{H}, \mathrm{R}^{2}=\mathrm{H}$<smiles>CC12CCCc3coc(c31)C(=O)c1cc3c(cc12)C(=O)C1=C3N2C[C@H](O)C[C@]2(O)C1</smiles>

225 13R, 23S; petroquinone $\mathrm{K}$ 226 13S, 23R; petroquinone $\mathrm{L}$<smiles>Cc1c2c(=O)c3occ4c3c(c-2c(=O)c2cc3c(=O)c5c(c(=O)c3cc12)NCCS5(=O)=O)CCC4</smiles>

220 adociaquinone $A$<smiles>CC1c2cc3c(OS(=O)(=O)O[Na])ccc(O)c3cc2C(=O)c2occ3c2C1CCC3</smiles>

239 xestoquinol sulfate<smiles></smiles>

$22716 R$, 23S; petroquinone I 228 16S, 23R; petroquinone $\mathrm{J}$<smiles></smiles>

221 adociaquinone $B$<smiles>CC1c2cc3c(cc2C(=O)c2occ4c2C1CCC4)C(=O)CCC3=O</smiles>

240

Figure 14. Monomeric halenaquinone derivatives isolated from tropical Petrosia sponges.

A series of halenaquinone derivatives-including eight monomers (218, 222-228), six dimers (229-234), and two trimers $(\mathbf{2 3 5}, \mathbf{2 3 6}$ - - were isolated from $P$. alfiani collected in Indonesia (Figures 14 and 15) [95]. The structures were identified based on their NMR spectra, ECD spectra, and DFT calculations. All compounds, except for 222 and 223, were evaluated for their inhibitory activity against ubiquitin-specific protease 7 (USP7), an enzyme related to the tumor suppression. All tested compounds exhibited potent activities with $\mathrm{IC}_{50}$ values of $0.1-2.0 \mu \mathrm{M}$. 
<smiles></smiles>

$x^{1}-x^{2}$ 229 petroquinone $G$<smiles>[Y][14CH3]</smiles>

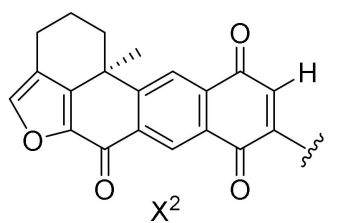

230 petroquinone $\mathrm{H}$

$$
x^{2} \cdot x^{2}
$$

231 petroquinone $F$

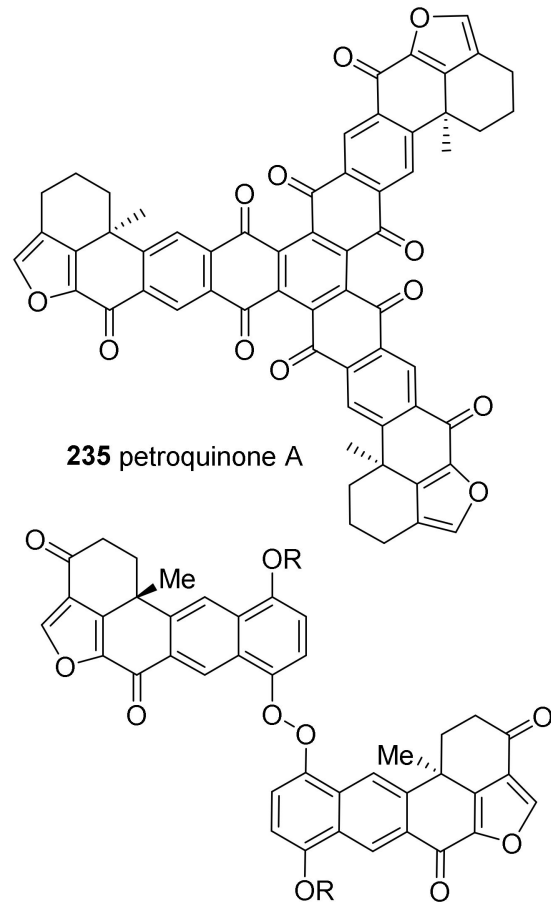<smiles>[X]c1cc(O[N+](=O)[O-])c([X])c2cc3c(cc12)C(=O)C(=O)c1occc1C3</smiles>

232 petroquinone $\mathrm{E}$

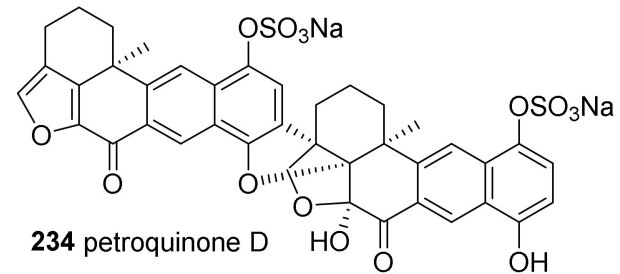

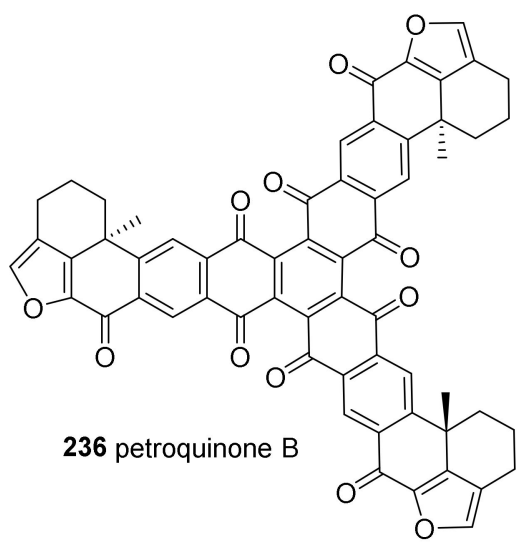

$241 \mathrm{R}=\mathrm{Me}$; dihalenaquinolide $\mathrm{A}$

$242 \mathrm{R}=\mathrm{CH}_{2} \mathrm{Me}$; dihalenaquinolide $\mathrm{B}$

Figure 15. Dimeric and trimeric halenquinone derivatives isolated from tropical Petrosia sponges.

The bioassay-guided separation of the extract of $P$. alfiani collected off the coast of Malaysia resulted in the isolation of xestoquinone derivatives (219-221, 237-240) (Figure 14) [96]. The extract selectively inhibited iron chelator-induced hypoxia-inducible factor-1 (HIF-1) in the human breast tumor (T47D) cell-based reporter assay, and adociaquinones A (220) and B (221) were proven to be the active pharmaceutical ingredients ( $\mathrm{IC}_{50} 0.2 \mu \mathrm{M}$ against HIF-1). Mechanistic studies revealed that both compounds promote oxygen consumption without affecting mitochondrial membrane potential. In addition, four compounds (219-221, 237) including adociaquinones $(220,221)$ exhibited potent cytotoxicity $\left(\mathrm{IC}_{50}, 2.6-6.5 \mu \mathrm{M}\right)$ against two human breast cancer cell lines, T47D and MDA-MB-231, in a cell viability assay.

The dimers of halenaquinol $(\mathbf{2 4 1}, \mathbf{2 4 2})$ connected through peroxide linkage have been isolated from P. elastica collected in Taiwan (Figure 15) [97]. In this study, halenaquinone (218) and halenaquinol could be obtained by degrading 241 . The natural dimers $(\mathbf{2 4 1}, \mathbf{2 4 2})$ exhibited higher growth inhibitory activity compared to the synthesized monomeric counterparts (218, halenaquinol) against human hepatoma cancer cells (Hep3B) at $10.0 \mu \mathrm{g} / \mathrm{mL}$ ( $5 \%$ versus $47 \%$ and $20 \%$, respectively).

A sesquiterpene-methylene quinone, puupehenone (243), was isolated from S. hartmani van Soest collected in the Bahamas (Figure 16) [98]. This compound was originally reported as a metabolite from a sponge of the genus Hetronema [99]. A sesquiterpene hydroquinone, strongylin A (244), was isolated from the same species later [100]. Strongylin 
A exhibited cytotoxicity against a murine leukemia cell line (P388) and influenza virus (PR8), with $\mathrm{IC}_{50}$ values of 13.0 and $6.5 \mu \mathrm{g} / \mathrm{mL}$, respectively.<smiles>CC1(C)CCC[C@@]2(C)C1CC[C@]1(C)OC3=CC(=O)C(O)=CC3=C[C@H]12</smiles>

243 puupehenone<smiles>COc1ccc(O)c(OC[C@]23CCCC(C)(C)[C@@H]2CC[C@@H](C)C3(C)C)c1C</smiles>

244 strongylin $A$

Figure 16. Merosesquiterpenoids isolated from S. hartmani.

\subsubsection{Saponins Isolated from Indonesian Petrosia sp.}

Lanostane-type triterpene oligoglycosides, sarasinosides (245-248), were isolated from the Indonesian Petrosia sponge (Figure 17) [101]. Sarasinosides were originally isolated from marine sponges of the genera Asteropus, Melophlus, and Lipastrotethya [102-104], which belong to the same subclass (Heteroscleromorpha) as Petrosia. Compound 245, named sarasinoside $\mathrm{S}$, was isolated for the first time and its structure was elucidated based on its spectroscopic data. None of these isolated sarasinosides exhibited cytotoxicity against human solid cancer cell lines, Huh-7 and A549, although some sarasinoside derivatives have been reported to exhibit weak cytotoxicity against several cancer cell lines.

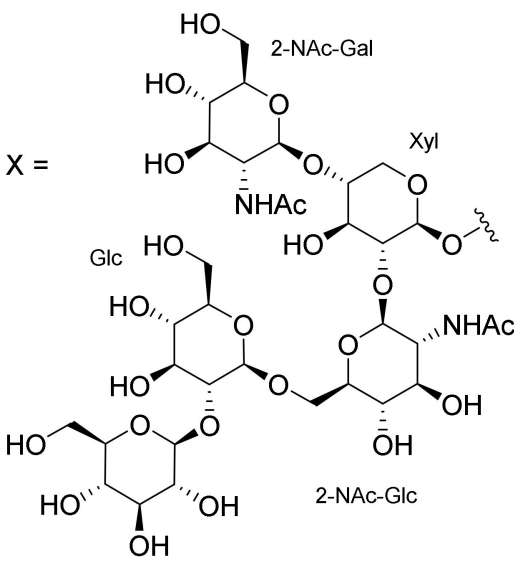

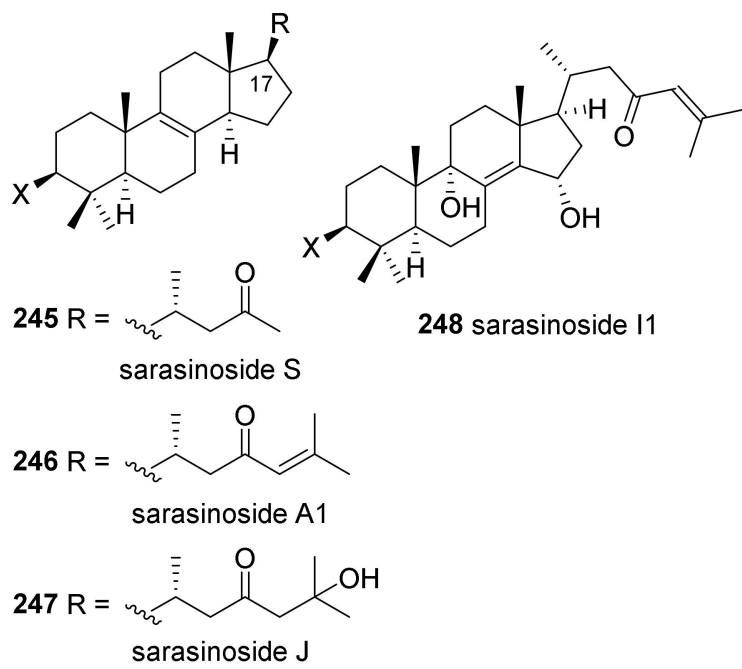

Figure 17. Saponins isolated from an Indonesian Petrosia sp.

\subsection{Alkaloids and Peptides}

2.3.1. Alkaloids Isolated from Tropical Petrosia Sponges

Several alkaloids have been isolated from Petrosia sponges inhabiting tropical regions, whereas no alkaloids from the temperate Petrosia have been reported. Petrosin (249), a bisquinolizidine isolated from P. seriata collected in Papua New Guinea, is the first reported Petrosia-derived alkaloid (Figure 18) [105]. 


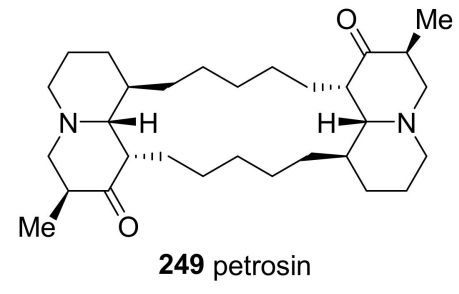

$250 \mathrm{R}^{1}=\mathrm{H}, \mathrm{R}^{2}=\mathrm{OMe}$; mimosamycin

$251 \mathrm{R}^{1}=\mathrm{NH}_{2}, \mathrm{R}^{2}=\mathrm{OMe}$

$252 \mathrm{R}^{1}=\mathrm{OH}, \mathrm{R}^{2}=\mathrm{NH}_{2}$<smiles>CC(=O)OCc1nccc2c1C(=O)C(O)=C(C(C)(C)C)C2=O</smiles><smiles>[R]O[C@H](C)[C@H]1c2cc(OC)cc(O)c2C=CN1C(=O)COC(C)(C)C</smiles><smiles>[R]C1=C(C)C(=O)c2c(ccnc2COC(=O)/C(C)=C\C)C1=O</smiles>

$255 \mathrm{R}=\mathrm{NHCH}_{2} \mathrm{CH}_{2} \mathrm{SO}_{3} \mathrm{H}$; cribrostatin 7 $256 \mathrm{R}=\mathrm{OMe}$; renierone $257 \mathrm{R}=\mathrm{OH}$<smiles>Cn1ccc2c3nc4cc(Br)ccc4c4c3c(c(=O)c-2c1)[N+](C)(CCl)CC4=O</smiles><smiles>Cn1ccc2c3c4ccc(Br)cc4nc4c(c-3c(=O)c-2c1)C[N+](C)(C)C=C4O</smiles><smiles>Cn1cc2c(cc1=O)-c1nc3cc(Br)ccc3c3ccnc(c13)C2=O</smiles>

258 petrosamine

259 2-bromoamphimedine

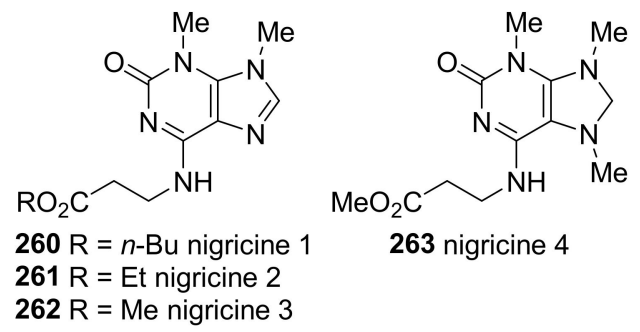<smiles>[R]c1ccc(CCNC(=N)N)cc1O</smiles>

Figure 18. Alkaloids isolated from tropical Petrosia sponges.

Isoquinoline alkaloids have been isolated from Petrosia sponges. Mimosamycin (250) and related derivatives (251-254) were isolated from Petrosia sp. and P. similis collected in India $[106,107]$. Isoquinoline quinones analogous to 254 (255-257) were isolated from two Philippine Petrosia sponges [108]. These compounds exhibited low cytotoxicity with an $\mathrm{IC}_{50}$ ranging from 24.0 to $45.0 \mathrm{\mu g} / \mathrm{mL}$ against the HCT116 human colon carcinoma cell line.

Petrosamine (258), a pyridoacridine alkaloid, was isolated from the Petrosia sp. collected in Belize [109]; it was confirmed to exist as a keto form by X-ray crystallography. However, a signal corresponding to that of a $C-5$ carbonyl group $\left(\delta_{C} 161 \mathrm{ppm}\right)$ was detected, which suggests that it takes an enol form in solution. 2-Bromoamphimedine (259) was isolated later from a Thai marine sponge along with 258 [110]. Compound 258 showed strong acetylcholinesterase inhibitory activity approximately six times higher than that of galantamine that used as a reference ( $\mathrm{IC}_{50} 0.09$ vs. $0.59 \mu \mathrm{M}$ ), while 259 was totally inactive.

Purine derivatives (260-263) conjugated with a $\beta$-amino acid were isolated from $P$. nigricans collected in Indonesia, and named nigricines [111]. None of these compounds showed cytotoxicity against the murine lymphoma cell line (L5178Y) at $10.0 \mu \mathrm{g} / \mathrm{mL}$, and no other activities could be measured due to the limited quantities obtained.

Phenethylguanidine alkaloids isolated from Indo-Pacific marine sponge $P$. cf. contignata, $(\mathbf{2 6 4}, \mathbf{2 6 5})$ are close derivatives of tubastrine [71]. Tubastrine was originally reported as a metabolite of the soft coral Tubastrea aurea, and compound $\mathbf{2 6 4}$ has previously been synthesized by the hydrogenation of tubastrine [112]. 


\subsubsection{Peptides Isolated from a Korean Petrosia sp.}

So far, only one article has reported the isolation of peptides from Petrosia sponge. This article described the isolation of five halicylindramides (266-270) from the Petrosia sp. collected in Korea (Figure 19) [113]. The structures of newly reported compounds (268-270) were elucidated based on their spectroscopic and mass data, and the stereochemistry was assigned by Marfey's method and ECD spectroscopy. The article points out that the producers of these compounds might be sponge-associated cyanobacteria, as all of the previously reported halicylindramides were discovered from the sponge Halichondria cylindrata. Compounds 266-268, bearing indole moiety at $R_{2}$ position, showed antagonistic activity against human farnesoid $\mathrm{X}$ receptor (hFXR) with $\mathrm{IC}_{50}$ values of $6.0,0.5$, and $5.0 \mu \mathrm{M}$, respectively, while $\mathbf{2 6 9}$ and $\mathbf{2 7 0}$ were inactive even at $100.0 \mu \mathrm{M}$.

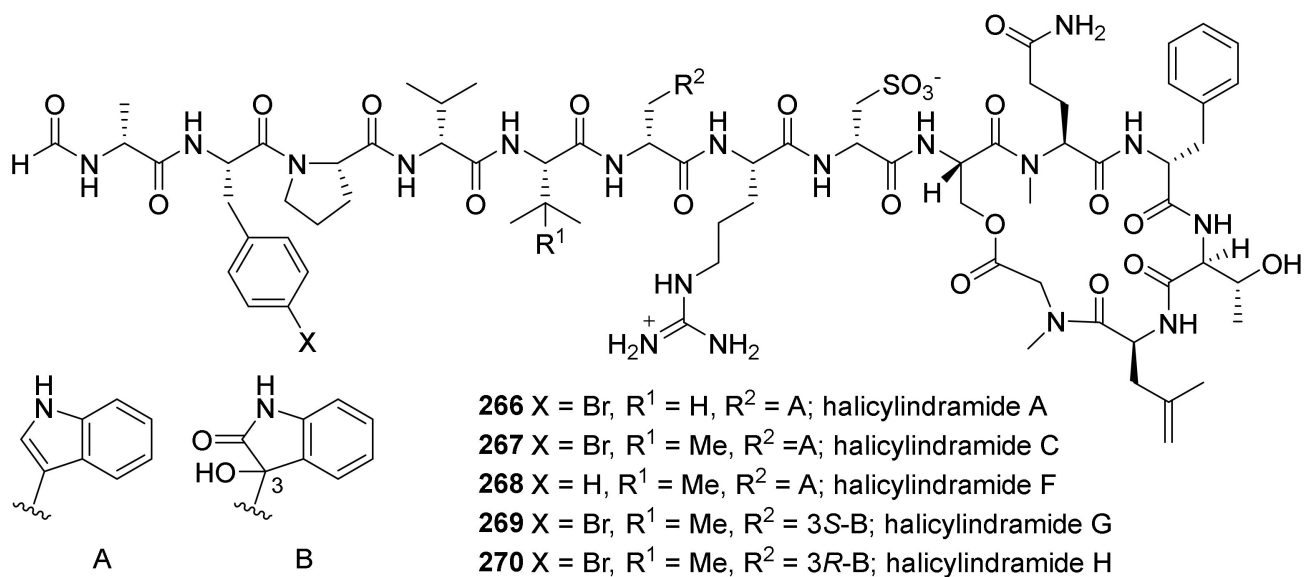

Figure 19. Depsipeptides isolated from a Korean Petrosia sp.

\subsection{Fatty Acid Derivatives}

A cyclitol derivative (271) was reported as a metabolite of Korean Petrosia sp. (Figure 20) [114]. This compound exhibited minimal cytotoxicity against a panel of human solid tumor cells with $\mathrm{IC}_{50}$ values around $10.0 \mu \mathrm{g} / \mathrm{mL}$; however, HeLa extractpromoted in vitro DNA replication was inhibited by the treatment of 271 in a dosedependent manner. Sphingolipid $\mathbf{2 7 2}$ was isolated from Red Sea Petrosia sp. and exhibited minimal cytotoxicity against MCF-7 and HepG2 cell lines with $\mathrm{IC}_{50}$ values around $20.0 \mu \mathrm{g} / \mathrm{mL}$ [69]. Brominated fatty acids (273-277) were isolated from the Caribbean Petrosia sp., and its structure was elucidated by mass spectrometry and chemical transformations, including deuteration with Wilkinson's catalyst [115].<smiles>CCCC(=O)OCC(O)COC1C(O)C(O)[C@@H](O)C1O</smiles>

271<smiles>CC(C)C/C=C\C(O)C(CO)NC(=O)CCC(C)C</smiles>
15

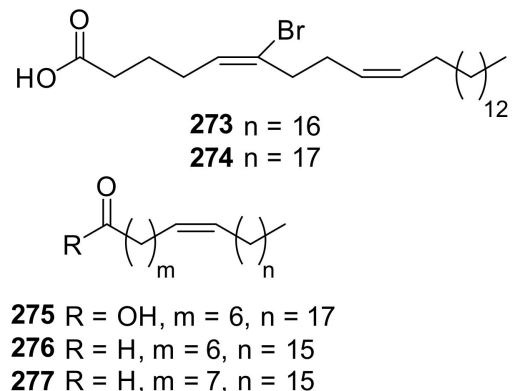

Figure 20. Fatty acid derivatives isolated from Petrosia sponges. 


\section{Discussion}

This review addressed 277 compounds isolated from Petrosia sponges from 87 peerreviewed articles (Figure 21). The type of predominant metabolite depended on the geographical location of the source sponge. Polyacetylenes were the most frequently found in Petrosia sponges inhabiting temperate regions. Of the 36 research articles regarding the metabolites isolated from sponges collected in the Mediterranean Sea, Korean waters, or the temperate regions of Japan, 29 reported the isolation of polyacetylenes. More than 100 polyacetylenes have been isolated from temperate Petrosia sponges, and 44 polyacetylenes were reported as the metabolites of tropical Petrosia sponges.

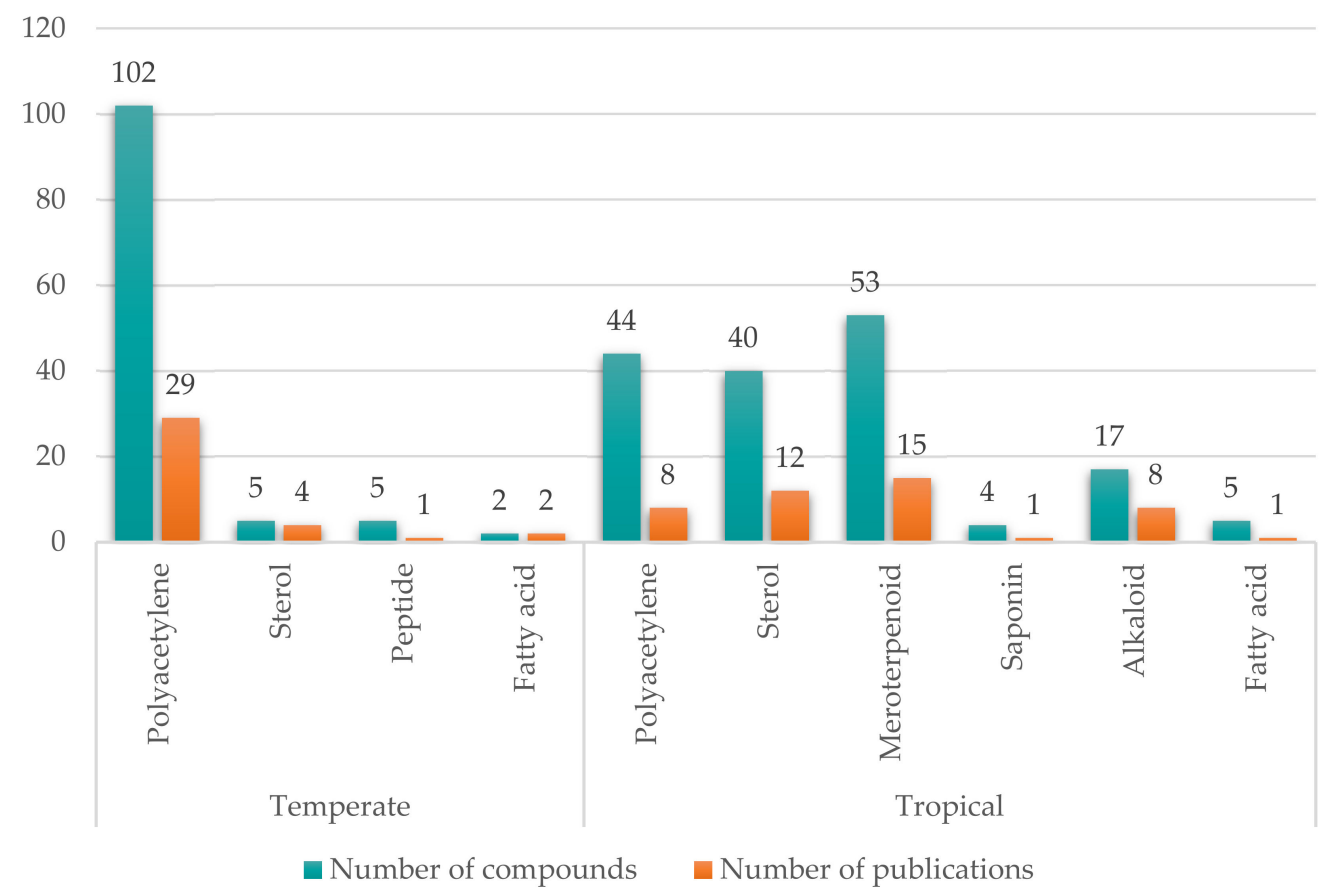

Figure 21. Number of compounds and publications for each type of Petrosia metabolites.

Meroterpenoids and sterols were the most frequently found metabolites in tropical Petrosia sponges; 15 and 12 articles of the 50 papers on the metabolites of tropical Petrosia sponges report a total of 53 meroditerpenoids and 40 steroids, respectively. There are only five reported sterols isolated from Petrosia collected in Italy and Japan, and no reported meroterpenoids have been isolated from temperate Petrosia sponges. Alkaloids have also only been isolated from tropical Petrosia sponges. Seventeen alkaloids have been reported in eight publications regarding the Petrosia sponges collected in the Philippines, Indonesia, Papua-New Guinea, India, Belize, and Saudi Arabia.

Saponins and peptides have also been isolated from Petrosia sponges, but they are not very common. Four noriterpene glycosides of the sarasinoside class were isolated from the Indonesian Petrosia sp., and five depsipeptides were isolated from a Korean Petrosia sponge. Considering the scarcity of these compounds, their origins might be the sponge-associated microbes.

All metabolites isolated from Petrosia sponges from temperate and tropical regions are summarized in Tables 1 and 2, respectively. 
Table 1. Metabolites isolated from Petrosia sponges in temperate region.

\begin{tabular}{|c|c|c|c|}
\hline Compound & Examined Biological Activity & Species & Reference \\
\hline \multicolumn{4}{|l|}{$\begin{array}{l}\text { Polyacetylenes } \\
\text { petroformynes }\end{array}$} \\
\hline $1-4$ & toxicity (fertilized sea urchin eggs, $A$. salina) & P. ficiformis & {$[28,29]$} \\
\hline $1-15,18-20,22-24$ & brine shrimp lethality & P. ficiformis & {$[30,31]$} \\
\hline $16,17,21,25$ & not reported & P. ficiformis & [32] \\
\hline \multicolumn{4}{|l|}{ petrosynol and petrosynone } \\
\hline 26,27 & toxicity (fertilized sea urchin eggs) & Petrosia sp. & {$[33,34]$} \\
\hline $28-31$ & $\begin{array}{c}\text { toxicity (fertilized ascidan eggs), brine } \\
\text { shrimp lethality }\end{array}$ & Petrosia sp. & {$[35]$} \\
\hline \multicolumn{4}{|l|}{ petroacetylene } \\
\hline 32 & $\begin{array}{l}\text { inhibition of the blastulation of } \\
\text { starfish embryo }\end{array}$ & Petrosia sp. & [36] \\
\hline \multicolumn{4}{|c|}{ petroformynes and neopetroformynes } \\
\hline \multicolumn{4}{|l|}{ durynes and miyakosynes } \\
\hline $37-42$ & cytotoxicity (HeLa) & Petrosia sp. & [39] \\
\hline $43-48$ & cytotoxicity (HeLa) & Petrosia sp. & [42] \\
\hline \multicolumn{4}{|l|}{ petrosynes } \\
\hline $49-50$ & not reported & Petrosia sp. & [43] \\
\hline \multicolumn{4}{|l|}{ corticatic acids } \\
\hline $51-53$ & antifungal activity (M. ramanniana) & P. corticata & {$[44]$} \\
\hline $54-55$ & inhibition of GGTase I from C. albicans & P. corticata & [45] \\
\hline \multicolumn{4}{|c|}{ petroformynes and petroformynic acids } \\
\hline \multicolumn{4}{|c|}{ petrocortynes and petrosiacetylenes } \\
\hline $58-60,84-87$ & brine shrimp lethality, RNA-cleaving activity & Petrosia sp. & [46] \\
\hline $61-65$ & cytotoxicity (K562) & Petrosia sp. & {$[47]$} \\
\hline $66-83,89,90$ & $\begin{array}{c}\text { cytotoxicity (A549, SK-OV-3, SK-MEL-2, } \\
\text { XF498, HCT-15) }\end{array}$ & Petrosia sp. & [48-51] \\
\hline $84-86,88$ & $\begin{array}{c}\text { cytotoxicity (A549, SK-OV-3, SK-MEL-2, } \\
\text { XF498, HCT-15) }\end{array}$ & Petrosia sp. & [52] \\
\hline $84-86,91$ & $\begin{array}{c}\text { cytotoxicity (NCI-H23, PC-3, ACHN, } \\
\text { NUGC-3, HCT-15) }\end{array}$ & Petrosia sp. & [53] \\
\hline \multicolumn{4}{|c|}{ petroraspailynes, raspailynes and petrosynol } \\
\hline \multicolumn{4}{|l|}{ Sterols } \\
\hline 187-188 & not reported & P. ficiformis & [77-79] \\
\hline 187-191 & not reported & P. corticata & [80] \\
\hline \multicolumn{4}{|l|}{$\begin{array}{l}\text { Peptides } \\
\text { halicylindramides }\end{array}$} \\
\hline $266-270$ & $\begin{array}{l}\text { antagonistic activity against human } \\
\text { farnesoid } X \text { receptor }\end{array}$ & Petrosia sp. & [113] \\
\hline \multicolumn{4}{|l|}{ Fatty acid derivatives } \\
\hline 271 & $\begin{array}{c}\text { cytotoxicity (A549, SK-OC-3, SK-MEL-2, } \\
\text { XF498, HCT-15) }\end{array}$ & Petrosia sp. & [114] \\
\hline 272 & cytotoxicity (MCF7, HepG2) & Petrosia sp. & [69] \\
\hline
\end{tabular}


Table 2. Metabolites isolated from Petrosia sponges in tropical region.

\begin{tabular}{|c|c|c|c|}
\hline Compound & Examined Biological Activity & Species & Reference \\
\hline \multicolumn{4}{|l|}{$\begin{array}{l}\text { Polyacetylenes } \\
\text { strongylodiols }\end{array}$} \\
\hline 103-105 & cytotoxicity (MOLT-4, IMR-90, DLD-1) & Petrosia sp. & [56] \\
\hline $106-112$ & not reported & Petrosia sp. & [57] \\
\hline \multicolumn{4}{|l|}{ strongylotriols and pellynols } \\
\hline $\begin{array}{l}1 \mathbf{1 3 - 1 1 7} \\
\text { strongylodiols and petrosiols }\end{array}$ & cytotoxicity (HeLa, K-562) & Petrosia sp. & [58] \\
\hline $105,106,118-122$ & induction of neuronal differentiation (PC-12) & P. strongylata & [59] \\
\hline $123-131$ & not reported & Petrosia sp. & [61] \\
\hline $132-136$ & cytotoxicity (NUGC) & P. durissima & [62] \\
\hline $\begin{array}{l}\text { pellynols and petrosynoic acids } \\
\qquad \mathbf{1 1 5}, \mathbf{1 3 7 - 1 4 4} \\
\text { aztèquynols }\end{array}$ & cytotoxicity (A2058, H522-T1, H460, IMR-90) & Petrosia sp. & [63] \\
\hline \multicolumn{4}{|l|}{ Sterols } \\
\hline 147 & not reported & P. durissima & {$[65,66]$} \\
\hline 148-151 & not reported & P. durissima & {$[67,68]$} \\
\hline 152-158 & cytotoxicity (HepG2, MCF7) & Petrosia sp. & [69] \\
\hline 159-174 & $\begin{array}{c}\text { cytotoxicity (MOLT-3, HepG2, A549, } \\
\text { HuCCA-1, HeLa, MDA-MB-231, MRC-5) }\end{array}$ & Petrosia sp. & {$[70]$} \\
\hline \multicolumn{4}{|l|}{ xestobergsterol $A$} \\
\hline \multicolumn{3}{|l|}{ cotignasterol } & [71] \\
\hline 176 & not reported & P. cotignata & [72] \\
\hline $\begin{array}{c}177-179 \\
\text { arthoesterols }\end{array}$ & cytotoxicity (KB, LoVo) & Petrosia sp. & [73] \\
\hline \multicolumn{4}{|l|}{ orthoesterols } \\
\hline \multicolumn{4}{|l|}{ weinbersterols } \\
\hline 185,186 & inhibition of thymidine phosphorylase & P. strongylata & [76] \\
\hline \multicolumn{4}{|l|}{$\begin{array}{l}\text { Meroterpenoids } \\
\text { strongylophorines }\end{array}$} \\
\hline 192-194 & not reported & P. durissima & [83] \\
\hline 195-199 & antimicrobial activity (B. subtilis, S. aureus) & P. durissima & [84] \\
\hline 192-194, 196, 200-202 & cytotoxicity (NUGC) & P. durissima & {$[62,85]$} \\
\hline $192-195,199,203-205,209,210$ & cytotoxicity (HeLa) & P. corticata & [86] \\
\hline 193-195, 199, 207-213 & $\begin{array}{c}\text { inhibition of the maturation of } \\
\text { starfish oocytes }\end{array}$ & P. strongylata & [87] \\
\hline $193,194,199,209,211,214,215$ & inhibition of protein tyrosine phosphatase $1 \mathrm{~B}$ & P. strongylata & {$[88]$} \\
\hline $193-195,199,203,207,208,214,215$ & chymotrypsin-like activity of proteasome & P. corticata & [89] \\
\hline 199,216 & cytotoxicity (MDA-231) & P. corticata & [90] \\
\hline 193-195, 217 & $\begin{array}{c}\text { antimicrobial activity (M. lueus, S. typhi, C. } \\
\text { cucumerinum), brine shrimp lethality }\end{array}$ & Petrosia sp. & [91] \\
\hline $218,222-236$ & inhibition of ubiquitin-specific protease 7 & P. alfiani & [95] \\
\hline $219-221,237-240$ & $\begin{array}{l}\text { inhibition of iron chelator-induced HIF-1, } \\
\text { cytotoxicity (T47D, MDA-MB-231) }\end{array}$ & P. alfiani & [96] \\
\hline \multicolumn{4}{|l|}{ dihalenaquinolides } \\
\hline 241,242 & cytotoxicity (Hep3B) & P. elastica & [97] \\
\hline \multicolumn{4}{|l|}{ puupehenone } \\
\hline \multicolumn{4}{|l|}{ strongylin A } \\
\hline 244 & cytotoxicity (P388), antiviral activity (PR8) & P. hartmani & [100] \\
\hline \multicolumn{4}{|l|}{ Saponins } \\
\hline $245-248$ & Cytotoxicity (Huh-7, A549) & Petrosia sp. & [101] \\
\hline
\end{tabular}


Table 2. Cont.

\begin{tabular}{|c|c|c|c|}
\hline Compound & Examined Biological Activity & Species & Reference \\
\hline \multicolumn{4}{|l|}{$\begin{array}{l}\text { Alkaloids } \\
\text { petrosin }\end{array}$} \\
\hline 249 & not reported & P. seriata & [105] \\
\hline $250-253$ & not reported & Petrosia sp. & [106] \\
\hline 254 & not reported & P. similis & [107] \\
\hline $255-257$ & cytotoxicity (HCT116) & Petrosia sp. & [108] \\
\hline \multicolumn{4}{|l|}{ petrosamine } \\
\hline 258 & not reported & Petrosia sp. & [109] \\
\hline 258,259 & inhibition of acetylcholinesterase & Petrosia sp. & [110] \\
\hline \multicolumn{4}{|l|}{ Nigricines } \\
\hline $260-263$ & cytotoxicity (L5178Y) & P. nigricans & [111] \\
\hline 264,265 & not reported & P. cf. contignata & [71] \\
\hline \multicolumn{4}{|l|}{ Fatty acid derivatives } \\
\hline $273-277$ & not reported & Petrosia sp. & [115] \\
\hline
\end{tabular}

Considering that the actual producers of natural products isolated from sponges are the microbes associated therein in many cases $[8,10]$, the latitudinal variation in metabolite composition of Petrosia sponges might be correlated with their associated microbial community. Genes involved in the biosynthesis of Petrosia metabolites have never been deduced until now; however, the biosynthetic gene clusters for analogous polyacetylenes, meroterpenoids, and terpenoids have been found from fungi, cyanobacteria, and actinomycetes. In addition, it has been reported for $P$. ficiformis that microbial symbiotic populations were more similar in genetically distinct individuals from the same location, than in genetically similar individuals from distant regions [116]. The factors which affects the structure of associated microbial community might be diverse and complex, as tropical and temperate seas have completely different ecosystems, not to mention physical factors, such as temperature and salinity. To better understand the factors that govern the composition of sponge metabolites, research to analyze the structure of associated microbial community of the sponges using various metagenomics tools should be conducted.

The biological activity most frequently investigated for Petrosia metabolites was cytotoxicity; most of the petrosiacetylenes showed growth inhibitory activity against human cancer cell lines. Research to better understand the ecological and pharmacological role of these compounds should be conducted. Biogenesis of Petrosia metabolites would be another significant topic in this field. This research would reveal the symbiotic relationships between marine sponges and microorganisms, and the strategies in biosynthesis that can be applied to the production of biologically-relevant molecules. In addition, the discovery of novel genes involved in the biosynthesis would provide potential bioengineering applications.

Author Contributions: Conceptualization, Y.-J.L.; investigation, Y.-J.L., Y.C., and H.N.K.T.; writingoriginal draft preparation, Y.-J.L.; writing-review and editing, Y.-J.L., Y.C., and H.N.K.T. All authors have read and agreed to the published version of the manuscript.

Funding: This research was funded by Korea Institute of Ocean Science and Technology, grant number PE99921.

Conflicts of Interest: The authors declare no conflict of interest.

\section{References}

1. Lindequist, U. Marine-derived pharmaceuticals-Challenges and opportunities. Biomol. Ther. 2016, 24, 561-571. [CrossRef]

2. Carroll, A.R.; Copp, B.R.; Davis, R.A.; Keyzers, R.A.; Prinsep, M.R. Marine natural products. Nat. Prod. Rep. 2019, 36, 122-173. [CrossRef]

3. Carroll, A.R.; Copp, B.R.; Davis, R.A.; Keyzers, R.A.; Prinsep, M.R. Marine natural products. Nat. Prod. Rep. 2020, 37, 175-223. [CrossRef] [PubMed]

4. Grosberg, R.K.; Vermeij, G.J.; Wainwright, P.C. Biodiversity in water and on land. Curr. Biol. 2012, 22, R900-R903. [CrossRef]

5. Proksch, P. Chemical defence in marine ecosystems (From APR Volume 3). Annu. Plant Rev. Online 2018, 3, 138-157. [CrossRef]

6. Hay, M.E. Marine chemical ecology: What's known and what's next? J. Exp. Mar. Biol. Ecol. 1996, 200, 103-134. [CrossRef] 
7. Hentschel, U.; Hopke, J.; Horn, M.; Friedrich, A.B.; Wagner, M.; Hacker, J.; Moore, B.S. Molecular evidence for a uniform microbial community in sponges from different cceans. Appl. Environ. Microbiol. 2002, 68, 4431-4440. [CrossRef] [PubMed]

8. Wang, G. Diversity and biotechnological potential of the sponge-associated microbial consortia. J. Ind. Microbiol. Biotechnol. 2006, 33, 545-551. [CrossRef]

9. Hardoim, C.C.P.; Costa, R.; Araújo, F.V.; Hajdu, E.; Peixoto, R.; Lins, U.; Rosado, A.S.; Van Elsas, J.D. Diversity of bacteria in the marine sponge Aplysina fulva in Brazilian coastal waters. Appl. Environ. Microbiol. 2009, 75, 3331-3343. [CrossRef] [PubMed]

10. Proksch, P.; Edrada, R.; Ebel, R. Drugs from the seas—current status and microbiological implications. Appl. Microbiol. Biotechnol. 2002, 59, 125-134. [CrossRef]

11. Hu, Y.; Chen, J.; Hu, G.; Yu, J.; Zhu, X.; Lin, Y.; Chen, S.; Yuan, J. Statistical research on the bioactivity of new marine natural products discovered during the 28 years from 1985 to 2012. Mar. Drugs 2015, 13, 202-221. [CrossRef]

12. Leal, M.C.; Puga, J.; Serôdio, J.; Gomes, N.C.M.; Calado, R. Trends in the discovery of new marine natural products from invertebrates over the last two decades-where and what are we bioprospecting? PLoS ONE 2012, 7, e30580. [CrossRef]

13. Proksch, P. Defensive roles for secondary metabolites from marine sponges and sponge-feeding nudibranchs. Toxicon 1994, 32, 639-655. [CrossRef]

14. Ruzicka, R.; Gleason, D.F. Latitudinal variation in spongivorous fishes and the effectiveness of sponge chemical defenses. Oecologia 2008, 154, 785-794. [CrossRef]

15. Pawlik, J.R.; Loh, T.-L.; McMurray, S.E.; Finelli, C.M. Sponge communities on Caribbean coral reefs are structured by factors that are top-down, not bottom-up. PLoS ONE 2013, 8, e62573. [CrossRef] [PubMed]

16. Poore, A.G.B.; Campbell, A.H.; Coleman, R.A.; Edgar, G.J.; Jormalainen, V.; Reynolds, P.L.; Sotka, E.E.; Stachowicz, J.J.; Taylor, R.B.; Vanderklift, M.A.; et al. Global patterns in the impact of marine herbivores on benthic primary producers. Ecol. Lett. 2012, 15, 912-922. [CrossRef]

17. Floeter, S.R.; Behrens, M.D.; Ferreira, C.E.L.; Paddack, M.J.; Horn, M.H. Geographical gradients of marine herbivorous fishes: Patterns and processes. Mar. Biol. 2005, 147, 1435-1447. [CrossRef]

18. Bakus, G.J.; Green, G. Toxicity in sponges and holothurians: A geographic pattern. Science 1974, 185, 951-953. [CrossRef]

19. Pawlik, J.; Chanas, B.; Toonen, R.; Fenical, W. Defenses of Caribbean sponges against predatory reef fish. I. Chemical deterrency. Mar. Ecol. Prog. Ser. 1995, 127, 183-194. [CrossRef]

20. Burns, E.; Ifrach, I.; Carmeli, S.; Pawlik, J.; Ilan, M. Comparison of anti-predatory defenses of Red Sea and Caribbean sponges. I. Chemical defense. Mar. Ecol. Prog. Ser. 2003, 252, 105-114. [CrossRef]

21. Becerro, M.A.; Thacker, R.W.; Turon, X.; Uriz, M.J.; Paul, V.J. Biogeography of sponge chemical ecology: Comparisons of tropical and temperate defenses. Oecologia 2003, 135, 91-101. [CrossRef] [PubMed]

22. Sacristan-Soriano, O.; Banaigs, B.; Becerro, M.A. Relevant spatial scales of chemical variation in Aplysina aerophoba. Mar. Drugs 2011, 9, 2499-2513. [CrossRef]

23. Rohde, S.; Gochfeld, D.J.; Ankisetty, S.; Avula, B.; Schupp, P.J.; Slattery, M. Spatial variability in secondary metabolites of the Indo-Pacific sponge Stylissa massa. J. Chem. Ecol. 2012, 38, 463-475. [CrossRef]

24. Bayona, L.M.; Van Leeuwen, G.; Erol, Ö.; Swierts, T.; Van Der Ent, E.; De Voogd, N.J.; Choi, Y.H. Influence of geographical location on the metabolic production of giant barrel sponges (Xestospongia spp.) revealed by metabolomics tools. ACS Omega 2020, 5, 12398-12408. [CrossRef] [PubMed]

25. Castiello, D.; Cimino, G.; De Rosa, S.; De Stefano, S.; Sodano, G. High molecular weight polyacetylenes from the nudibranch Peltodoris actromaculata and the sponge Petrosia ficiformis. Tetrahedron Lett. 1980, 21, 5047-5050. [CrossRef]

26. Cimino, G.; De Giulio, A.; De Rosa, S.; De Stefano, S.; Sodano, G. Further high molecular weight polyacetylenes from the sponge Petrosia ficiformis. J. Nat. Prod. 1985, 48, 22-27. [CrossRef]

27. Cimino, G.; Crispino, A.; De Rosa, S.; De Stefano, S.; Sodano, G. Polyacetylenes from the sponge Petrosia ficiformis found in dark caves. Cell. Mol. Life Sci. 1981, 37, 924-926. [CrossRef]

28. Cimino, G.; De Giulio, A.; De Rosa, S.; Di Marzo, V. High molecular weight polyacetylenes from Petrosia ficiformis: Further structural analysis and biological activity. Tetrahedron Lett. 1989, 30, 3563-3566. [CrossRef]

29. Guo, Y.; Gavagnin, M.; Trivellone, E.; Cimino, G. Absolute stereochemistry of petroformynes, high molecular polyacetylenes from the marine sponge Petrosia ficiformis. Tetrahedron 1994, 50, 13261-13268. [CrossRef]

30. Cimino, G.; De Giulio, A.; De Rosa, S.; Di Marzo, V. Minor bioactive polyacetylenes from Petrosia ficiformis. J. Nat. Prod. 1990, 53, 345-353. [CrossRef]

31. Guo, Y.; Gavagnin, M.; Trivellone, E.; Cimino, G. Further structural studies on the petroformynes. J. Nat. Prod. 1995, 58, 712-722. [CrossRef]

32. Guo, Y.; Gavagnin, M.; Salierno, C.; Cimino, G. Further petroformynes from both Atlantic and Mediterranean populations of the sponge Petrosia ficiformis. J. Nat. Prod. 1998, 61, 333-337. [CrossRef]

33. Fusetani, N.; Kato, Y.; Matsunaga, S.; Hashimoto, K. Bioactive marine metabolites III. A novel polyacetylene alcohol, inhibitor of cell division in fertilized sea urchin eggs, from the marine sponge Petrosia sp. Tetrahedron Lett. 1983, 24, 2771-2774. [CrossRef]

34. Fusetani, N.; Shiragaki, T.; Matsunaga, S.; Hashimoto, K. Bioactive marine metabolites. 20. Petrosynol and petrosynone, antimicrobial C30 polyacetylenes from the marine sponge Petrosia sp.: Determination of the absolute configuration. Tetrahedron Lett. 1987, 28, 4313-4314. [CrossRef] 
35. Ochi, M.; Ariki, S.; Tatsukawa, A.; Kotsuki, H.; Fukuyama, Y.; Shibata, K. Bioactive polyacetylenes from the marine sponge Petrosia sp. Chem. Lett. 1994, 89-92. [CrossRef]

36. Ohta, S.; Ogawa, T.; Ohta, E.; Ikeuchi, T.; Kamemura, K.; Ikegami, S. Petroacetylene, a new polyacetylene from the marine sponge Petrosia solida that inhibits blastulation of starfish embryos. Nat. Prod. Res. 2013, 27, 1842-1847. [CrossRef]

37. Okamoto, C.; Nakao, Y.; Fujita, T.; Iwashita, T.; Van Soest, R.W.M.; Fusetani, N.; Matsunaga, S. Cytotoxic C47-polyacetylene carboxylic acids from a marine sponge Pertrosia sp. J. Nat. Prod. 2007, 70, 1816-1819. [CrossRef] [PubMed]

38. Ueoka, R.; Ise, Y.; Matsunaga, S. Cytotoxic polyacetylenes related to petroformyne-1 from the marine sponge Petrosia sp. Tetrahedron 2009, 65, 5204-5208. [CrossRef]

39. Hitora, Y.; Takada, K.; Okada, S.; Ise, Y.; Matsunaga, S. (-)-Duryne and its homologues, cytotoxic acetylenes from a marine sponge Petrosia sp. J. Nat. Prod. 2011, 74, 1262-1267. [CrossRef] [PubMed]

40. Wright, A.E.; McConnell, O.J.; Kohmoto, S.; Lui, M.S.; Thompson, W.; Snader, K.M. Duryne, a new cytotoxic agent from the marine sponge Cribrochalinadura. Tetrahedron Lett. 1987, 28, 1377-1380. [CrossRef]

41. Gung, B.W.; Omollo, A.O. Total synthesis of (+)- and (-)-duryne: A potent anticancer agent from the marine sponge cribrochalina Dura. Establishment of the central double bond geometry and the absolute configuration of the chiral centers. J. Org. Chem. 2008, 73, 1067-1070. [CrossRef]

42. Hitora, Y.; Takada, K.; Okada, S.; Matsunaga, S. Miyakosynes A-F, cytotoxic methyl branched acetylenes from a marine sponge Petrosia sp. Tetrahedron 2011, 67, 4530-4534. [CrossRef]

43. Iguchi, K.; Kitade, M.; Kashiwagi, T.; Yamada, Y. Structure and synthesis of petrosynes, new acetylenic enol ether glycerides from the Okinawan marine sponge of the genus Petrosia. J. Org. Chem. 1993, 58, 5690-5698. [CrossRef]

44. Li, H.-Y.; Matsunaga, S.; Fusteani, N. Bioactive marine metabolites. corticatic acids A-C, antifungal acetylenic acids from the marine sponge, Petrosia corticata. J. Nat. Prod. 1994, 57, 1464-1467. [CrossRef] [PubMed]

45. Nishimura, S.; Matsunaga, S.; Shibazaki, M.; Suzuki, K.; Harada, N.; Naoki, H.; Fusetani, N. Corticatic Acids D and E, polyacetylenic geranylgeranyltransferase type I inhibitors, from the marine sponge Petrosia corticata. J. Nat. Prod. 2002, 65, 1353-1356. [CrossRef] [PubMed]

46. Seo, Y.; Cho, K.W.; Rho, J.-R.; Shin, J.; Sim, C.J. Petrocortynes and petrosiacetylenes, novel polyacetylenes from a sponge of the genus Petrosia. Tetrahedron 1998, 54, 447-462. [CrossRef]

47. Shin, J.; Seo, Y.; Cho, K.W. Five new polyacetylenes from a sponge of the genus Petrosia. J. Nat. Prod. 1998, 61, 1268-1273. [CrossRef]

48. Kim, J.S.; Lim, Y.J.; Im, K.S.; Jung, J.H.; Shim, C.J.; Lee, C.O.; Hong, J.; Lee, H. Cytotoxic polyacetylenes from the marine sponge Petrosia sp. J. Nat. Prod. 1999, 62, 554-559. [CrossRef]

49. Lim, Y.J.; Kim, J.S.; Im, K.S.; Jung, J.H.; Lee, C.-O.; Hong, J.; Kim, D.-K. New Cytotoxic polyacetylenes from the marine sponge Petrosia. J. Nat. Prod. 1999, 62, 1215-1217. [CrossRef]

50. Lim, Y.J.; Park, H.S.; Im, K.S.; Lee, C.-O.; Hong, J.; Lee, M.-Y.; Kim, D.-K.; Jung, J.H. Additional cytotoxic polyacetylenes from the marine sponge Petrosia species. J. Nat. Prod. 2001, 64, 46-53. [CrossRef]

51. Lim, Y.J.; Lee, C.-O.; Hong, J.; Kim, D.-K.; Im, K.S.; Jung, J.H. Cytotoxic polyacetylenic alcohols from the marine sponge Petrosia species. J. Nat. Prod. 2001, 64, 1565-1567. [CrossRef]

52. Kim, J.S.; Im, K.S.; Jung, J.H.; Kim, Y.-L.; Kim, J.; Shim, C.J.; Lee, C.-O. New bioactive polyacetylenes from the marine sponge Petrosia sp. Tetrahedron 1998, 54, 3151-3158. [CrossRef]

53. Lee, Y.-J.; Yoo, S.-J.; Kang, J.S.; Yun, J.; Shin, H.J.; Lee, J.S.; Lee, H.-S. Cytotoxic petrosiacetylenes from the marine sponge Petrosia sp. Lipids 2013, 48, 87-91. [CrossRef]

54. Seo, Y.; Cho, K.W.; Lee, H.-S.; Rho, J.-R.; Shin, J. New acetylenic enol ethers of glycerol from the sponge Petrosia sp. J. Nat. Prod. 1999, 62, 122-126. [CrossRef] [PubMed]

55. Guella, G.; Mancini, I.; Pietra, F. Raspailynes, novel long-chain acetylenic enol ethers of glycerol from the marine sponges Raspailia pumila and Raspailia ramosa. Helv. Chim. Acta 1987, 70, 1050-1062. [CrossRef]

56. Watanabe, K.; Tsuda, Y.; Yamane, Y.; Takahashi, H.; Iguchi, K.; Naoki, H.; Fujita, T.; Van Soest, R.W. Strongylodiols A, B and C, new cytotoxic acetylenic alcohols isolated from the Okinawan marine sponge of the genus Strongylophora as each enantiomeric mixture with a different ratio. Tetrahedron Lett. 2000, 41, 9271-9276. [CrossRef]

57. Watanabe, K.; Tsuda, Y.; Hamada, M.; Omori, M.; Mori, G.; Iguchi, K.; Naoki, H.; Fujita, T.; Van Soest, R.W.M. Acetylenic strongylodiols from a Petrosia (Strongylophora) Okinawan marine sponge. J. Nat. Prod. 2005, 68, 1001-1005. [CrossRef] [PubMed]

58. Gabriel, A.F.; Li, Z.; Kusuda, R.; Tanaka, C.; Miyamoto, T. Six new polyacetylenic alcohols from the marine sponges Petrosia sp. and Halichondria sp. Chem. Pharm. Bull. 2015, 63, 469-475. [CrossRef] [PubMed]

59. Horikawa, K.; Yagyu, T.; Yoshioka, Y.; Fujiwara, T.; Kanamoto, A.; Okamoto, T.; Ojika, M. Petrosiols A-E, neurotrophic diyne tetraols isolated from the Okinawan sponge Petrosia strongylata. Tetrahedron 2013, 69, 101-106. [CrossRef]

60. Higashibayashi, S.; Czechtizky, W.; Kobayashi, Y.; Kishi, Y. Universal NMR databases for contiguous polyols. J. Am. Chem. Soc. 2003, 125, 14379-14393. [CrossRef]

61. Watanabe, K.; Mori, G.; Iguchi, K.; Suzuki, M.; Van Soest, R.W.M. Nine acetylenic alcohols isolated from the Okinawan marine sponge of the genus Petrosia (Strongylophora). Nat. Prod. Res. 2007, 21, 710-720. [CrossRef] [PubMed]

62. Shen, Y.-C.; Prakash, C.V.S. Two new acetylenic derivatives and a new meroditerpenoid from a Taiwanese marine sponge Strongylophora durissima. J. Nat. Prod. 2000, 63, 1686-1688. [CrossRef] [PubMed] 
63. Mejia, E.J.; Magranet, L.B.; De Voogd, N.J.; TenDyke, K.; Qiu, D.; Shen, Y.Y.; Zhou, Z.; Crews, P. Structures and cytotoxic evaluation of new and known acyclic ene-ynes from an American Samoa Petrosia sp. sponge. J. Nat. Prod. 2012, 76, 425-432. [CrossRef]

64. Guerriero, A.; Debitus, C.; Laurent, D.; D'Ambrosio, M.; Pietra, F. Aztequynol A, the first clearly defined, C-branched polyacetylene and the analog aztequynol B. Isolation from the tropical marine sponge Petrosia sp. Tetrahedron Lett. 1998, 39, 6395-6398. [CrossRef]

65. Bortolotto, M.; Braekman, J.C.; Daloze, D.; Tursch, B. Chemical studies of marine invertebrates. XXXVI. Strongylosterol, a novel C-30 sterol from the sponge Strongylophora durissima Dendy. Bull. Soc. Chim. Belg. 1978, 87, 539-543. [CrossRef]

66. Theobald, N.; Djerassi, C. Determination of the absolute configuration of stelliferasterol and strongylosterol-Two marine sterols with "extended" side chains. Tetrahedron Lett. 1978, 19, 4369-4372. [CrossRef]

67. Li, L.N.; Djerassi, C. Minor and trace sterols in marine invertebrates. 23. Xestospongesterol and isoxestospongesterol-First examples of quadruple biomethylation of the sterol side chain. J. Am. Chem. Soc. 1981, 103, 3606-3608. [CrossRef]

68. Li, L.N.; Djerassi, C. Minor and trace sterols in marine invertebrates. 30. Isolation, structure elucidation, and partial synthesis of 26-methylstrongylosterol and 28-methylxestosterol, two marine sterols arising by a novel quadrupole biomethylation sequence. Tetrahedron Lett. 1981, 22, 4639-4642. [CrossRef]

69. Abdel-Lateff, A.; Alarif, W.M.; Asfour, H.Z.; Ayyad, S.-E.N.; Khedr, A.; Badria, F.A.; Al-Lihaibi, S.S. Cytotoxic effects of three new metabolites from Red Sea marine sponge, Petrosia sp. Environ. Toxicol. Pharmacol. 2014, 37, 928-935. [CrossRef] [PubMed]

70. Pailee, P.; Mahidol, C.; Ruchirawat, S.; Prachyawarakorn, V. Sterols from Thai marine sponge Petrosia (Strongylophora) sp. and their cytotoxicity. Mar. Drugs 2017, 15, 54-65. [CrossRef] [PubMed]

71. Sperry, S.; Crews, P. Dihydrotubastrines: Phenethylguanidine analogs from the Indo-Pacific marine sponge Petrosia cf. contignata. J. Nat. Prod. 1998, 61, 859-861. [CrossRef] [PubMed]

72. Burgoyne, D.L.; Andersen, R.J.; Allen, T.M. Contignasterol, a highly oxygenated steroid with the unnatural $14 \beta$ configuration from the marine sponge Petrosia contignata Thiele, 1899. J. Org. Chem. 1992, 57, 525-528. [CrossRef]

73. Corgiat, J.M.; Scheuer, P.J.; Steiner, J.L.R.; Clardy, J. Three pregnane-10,2-carbolactones from a sponge, Strongylophora sp. Tetrahedron 1993, 49, 1557-1562. [CrossRef]

74. Koehn, F.E.; Gunasekera, M.; Cross, S.S. New antiviral sterol disulfate ortho esters from the marine sponge Petrosia weinbergi. J. Org. Chem. 1991, 56, 1322-1325. [CrossRef]

75. Sun, H.H.; Gross, S.S.; Gunasekera, M.; Koehn, F.E. Weinbersterol disulfates A and B, antiviral steroid sulfates from the sponge petrosia weinbergi. Tetrahedron 1991, 47, 1185-1190. [CrossRef]

76. Aoki, S.; Naka, Y.; Itoh, T.; Furukawa, T.; Rachmat, R.; Akiyama, S.-I.; Kobayashi, M. Lembehsterols A and B, novel sulfated sterols inhibiting thymidine phosphorylase, from the marine sponge Petrosia strongylata. Chem. Pharm. Bull. 2002, 50, 827-830. [CrossRef]

77. Sica, D.; Zollo, F. Petrosterol, the major sterol with a cyclopropane side chain in the sponge Petrosia ficiformis. Tetrahedron Lett. 1978, 19, 837-838. [CrossRef]

78. Mattia, C.; Mazzarella, L.; Puliti, R.; Sica, D.; Zollo, F. X-ray crystal structure determination of petrosterol p-bromobenzoate. A revision. Tetrahedron Lett. 1978, 19, 3953-3954. [CrossRef]

79. Khalil, M.W.; Durham, L.J.; Djerassi, C.; Sica, D. Minor and trace sterols in marine invertebrates. 15. Ficisterol (23-ethyl-24-methyl27-norcholesta-5,25-dien-3.beta.-ol). A biosynthetically unprecedented sterol from the marine sponge Petrosia ficiformis. J. Am. Chem. Soc. 1980, 102, 2133-2134. [CrossRef]

80. Umeyama, A.; Ito, S.; Yoshigaki, A.; Arihara, S. Two new 26,27-cyclosterols from the marine sponge Strongylophora corticata. J. Nat. Prod. 2000, 63, 1540-1542. [CrossRef]

81. Li, L.N.; Li, H.T.; Lang, R.W.; Itoh, T.; Sica, D.; Djerassi, C. Minor and trace sterols in marine invertebrates. 31. Isolation and structure elucidation of $23 \mathrm{H}$-isocalysterol, a naturally occurring cyclopropene. Some comparative observations on the course of hydrogenolytic ring opening of steroidal cyclopropenes and cyclopropanes. J. Am. Chem. Soc. 1982, 104, 6726-6732. [CrossRef]

82. Menna, M.; Imperatore, C.; D'Aniello, F.; Aiello, A. Meroterpenes from marine invertebrates: Structures, occurrence, and ecological implications. Mar. Drugs 2013, 11, 1602-1643. [CrossRef]

83. Braekman, J.C.; Daloze, D.; Hulot, G.; Tursch, B.; Declercq, J.P.; Germain, G.; Van Meerssche, M. Chemical studies of marine invertebrates. XXXVII. Three novel meroditerpenoids from the sponge Strongylophora durissima. Bull. Soc. Chim. Belg. 1978, 87, 917. [CrossRef]

84. Salva, J.; Faulkner, D.J. Metabolites of the sponge Strongylophora durissima from Maricaban Island, Philippines. J. Org. Chem. 1990, 55, 1941-1943. [CrossRef]

85. Shen, Y.-C.; Hung, M.-C.; Prakash, C.V.S.; Wang, J.-J. New meroditerpenoids from a Taiwanese marine sponge Strongylophora durissima. J. Chin. Chem. Soc. 2000, 47, 567-570. [CrossRef]

86. Hoshino, A.; Mitome, H.; Miyaoka, H.; Shintani, A.; Yamada, Y.; Van Soest, R.W.M. New strongylophorines from the Okinawan marine sponge Petrosia (Strongylophora) corticata. J. Nat. Prod. 2003, 66, 1600-1605. [CrossRef] [PubMed]

87. Liu, H.; Namikoshi, M.; Akano, K.; Kobayashi, H.; Nagai, H.; Yao, X. Seven new meroditerpenoids, from the marine sponge Strongylophora strongylata, that inhibited the maturation of starfish oocytes. J. Asian Nat. Prod. Res. 2005, 7, 661-670. [CrossRef] [PubMed] 
88. Lee, J.-S.; Abdjul, D.B.; Yamazaki, H.; Takahashi, O.; Kirikoshi, R.; Ukai, K.; Namikoshi, M. Strongylophorines, new protein tyrosine phosphatase 1B inhibitors, from the marine sponge Strongylophora strongilata collected at Iriomote Island. Bioorganic Med. Chem. Lett. 2015, 25, 3900-3902. [CrossRef]

89. Noda, A.; Sakai, E.; Kato, H.; Losung, F.; Mangindaan, R.E.; De Voogd, N.J.; Yokosawa, H.; Tsukamoto, S. Strongylophorines, meroditerpenoids from the marine sponge Petrosia corticata, function as proteasome inhibitors. Bioorg. Med. Chem. Lett. 2015, 25, 2650-2653. [CrossRef]

90. Warabi, K.; McHardy, L.M.; Matainaho, L.; Van, S.R.; Roskelley, C.D.; Roberge, M.; Andersen, R.J. Strongylophorine-26, a new meroditerpenoid isolated from the marine sponge Petrosia (Strongylophora) corticata that exhibits anti-invasion activity. J. Nat. Prod. 2004, 67, 1387-1389. [CrossRef]

91. Balbin-Oliveros, M.; Edrada, R.A.; Proksch, P.; Wray, V.; Witte, L.; Van Soest, R.W.M. A new meroditerpenoid dimer from an undescribed Philippine marine sponge of the genus Strongylophora. J. Nat. Prod. 1998, 61, 948-952. [CrossRef] [PubMed]

92. Roll, D.M.; Scheuer, P.J.; Matsumoto, G.K.; Clardy, J. Halenaquinone, a pentacyclic polyketide from a marine sponge. J. Am. Chem. Soc. 1983, 105, 6177-6178. [CrossRef]

93. Nakamura, H.; Kobayashi, J.i.; Kobayashi, M.; Ohizumi, Y.; Hirata, Y. Physiologically active marine natural products from Porifera. VII. Xestoquinone. A novel cardiotonic marine natural product isolated from the Okinawan sea sponge Xestospongia sapra. Chem. Lett. 1985, 713. [CrossRef]

94. Schmitz, F.J.; Bloor, S.J. Xesto- and halenaquinone derivatives from a sponge, Adocia sp., from Truk lagoon. J. Org. Chem. 1988, 53, 3922-3925. [CrossRef]

95. Tanokashira, N.; Kukita, S.; Kato, H.; Nehira, T.; Angkouw, E.D.; Mangindaan, R.E.; de Voogd, N.J.; Tsukamoto, S. Petroquinones: Trimeric and dimeric xestoquinone derivatives isolated from the marine sponge Petrosia alfiani. Tetrahedron 2016, 72 , 5530-5540. [CrossRef]

96. Du, L.; Mahdi, F.; Datta, S.; Jekabsons, M.B.; Zhou, Y.-D.; Nagle, D.G. Structures and mechanisms of antitumor agents: Xestoquinones uncouple cellular respiration and disrupt HIF signaling in human breast tumor cells. J. Nat. Prod. 2012, 75, 1553-1559. [CrossRef]

97. Shen, Y.C.; Prakash, C.V.S.; Guh, J.-H. New pentacyclic polyketide dimeric peroxides from a Taiwanese marine sponge Petrosia elastica. Tetrahedron Lett. 2004, 45, 2463-2466. [CrossRef]

98. Kohmoto, S.; McConnell, O.J.; Wright, A.; Koehn, F.; Thompson, W.; Lui, M.; Snader, K.M. Puupehenone, a cytotoxic metabolite from a deep water marine sponge, Stronglyophora hartmani. J. Nat. Prod. 1987, 50, 336. [CrossRef]

99. Ravi, B.N.; Perzanowski, H.P.; Ross, R.A.; Erdman, T.R.; Scheuer, P.J.; Finer, J.; Clardy, J. Recent research in marine natural products: The puupehenones. Pure Appl. Chem. 1979, 51, 1893-1900. [CrossRef]

100. Wright, A.E.; Rueth, S.A.; Cross, S.S. An antiviral sesquiterpene hydroquinone from the marine sponge Strongylophora hartmani. J. Nat. Prod. 1991, 54, 1108-1111. [CrossRef] [PubMed]

101. Maarisit, W.; Yamazaki, H.; Kanno, S.-I.; Tomizawa, A.; Rotinsulu, H.; Wewengkang, D.S.; Sumilat, D.A.; Ukai, K.; Kapojos, M.M.; Namikoshi, M. A tetramic acid derivative with protein tyrosine phosphatase 1B inhibitory activity and a new nortriterpene glycoside from the Indonesian marine sponge Petrosia sp. Bioorganic Med. Chem. Lett. 2017, 27, 999-1002. [CrossRef] [PubMed]

102. Espada, A.; Jiménez, C.; Rodriguez, J.; Crews, P.; Riguera, R. Sarasinosides D-G: Four new triterpenoid saponins from the sponge asteropus sarasinosum. Tetrahedron 1992, 48, 8685-8696. [CrossRef]

103. Santalova, E.A.; Denisenko, V.A.; Dmitrenok, P.S.; Berdyshev, D.V.; Stonik, V.A. Two new sarasinosides from the sponge Melophlus Sarasinorum. Nat. Prod. Commun. 2006, 1. 1934578X0600100401. [CrossRef]

104. Lee, J.-H.; Jeon, J.-E.; Lee, Y.-J.; Lee, H.-S.; Sim, C.J.; Oh, K.-B.; Shin, J. Nortriterpene glycosides of the sarasinoside class from the sponge Lipastrotethya sp. J. Nat. Prod. 2012, 75, 1365-1372. [CrossRef]

105. Braekman, J.C.; Daloze, D.; Macedo de Abreu, P.; Piccinni-Leopardi, C.; Germain, G.; Van Meerssche, M. A novel type of bisquinolizidine alkaloid from the sponge Petrosia seriata. Tetrahedron Lett. 1982, 23, 4277-4280. [CrossRef]

106. Kobayashi, M.; Rao, S.R.; Chavakula, R.; Sarma, N.S. Mimosamycin, 4-aminomimosamycin and 7-amino-7-demethoxymimosamycin from the Petrosia sp. of sponge. J. Chem. Res. Synop. 1994, 25, 282-283. [CrossRef]

107. Ramesh, P.; Reddy, N.S.; Venkateswarlu, Y. A new 1,2-dihydroisoquinoline from the sponge Petrosia similis. J. Nat. Prod. 1999, 62, 780-781. [CrossRef]

108. Sandoval, I.T.; Davis, R.A.; Bugni, T.S.; Concepcion, G.P.; Harper, M.K.; Ireland, C.M. Cytotoxic isoquinoline quinones from sponges of the genus Petrosia. Nat. Prod. Res. 2004, 18, 89-93. [CrossRef]

109. Molinski, T.F.; Fahy, E.; Faulkner, D.J.; Van Duyne, G.D.; Clardy, J. Petrosamine, a novel pigment from the marine sponge Petrosia sp. J. Org. Chem. 1988, 53, 1340-1341. [CrossRef]

110. Nukoolkarn, V.S.; Saen-Oon, S.; Rungrotmongkol, T.; Hannongbua, S.; Ingkaninan, K.; Suwanborirux, K. Petrosamine, a potent anticholinesterase pyridoacridine alkaloid from a Thai marine sponge Petrosia sp. Bioorg. Med. Chem. 2008, 16, 6560-6567. [CrossRef]

111. Ashour, M.; Edrada-Ebel, R.; Ebel, R.; Wray, V.; Van Soest, R.; Proksch, P. New purine derivatives from the marine sponge Petrosia nigricans. Nat. Prod. Commun. 2008, 3, 1889-1894. [CrossRef]

112. Ryuichi, S.; Tatsuo, H. Tubastrine, a new guanidinostyrene from the coral Tubastrea aurea. Chem. Lett. 1987, 16, 127-128. [CrossRef] 
113. Hahn, D.; Kim, H.; Yang, I.; Chin, J.; Hwang, H.; Won, D.H.; Lee, B.; Nam, S.-J.; Ekins, M.; Choi, H.; et al. The halicylindramides, farnesoid $X$ receptor antagonizing depsipeptides from a Petrosia sp. marine sponge collected in Korea. J. Nat. Prod. 2015, 79, 499-506. [CrossRef]

114. Kim, D.-K.; Lim, Y.J.; Kim, J.S.; Park, J.H.; Kim, N.D.; Im, K.S.; Hong, J.; Jung, J.H. A cyclitol derivative as a replication inhibitor from the marine sponge Petrosia sp. J. Nat. Prod. 1999, 62, 773-776. [CrossRef]

115. Carballeira, N.M.; Shalabi, F. Novel brominated phospholipid fatty acids from the Caribbean sponge Petrosia sp. J. Nat. Prod. 1993, 56, 739-746. [CrossRef]

116. Burgsdorf, I.; Haber, M.; Steindler, L.; Erwin, P.M.; Lopez-Legentil, S.; Cerrano, C.; Frenk, S. Biogeography rather than association with cyanobacteria structures symbiotic microbial communities in the marine sponge Petrosia ficiformis. Front. Microbiol. 2014, 5, 529-539. [CrossRef] 